\title{
Characterization of NMB, GRP and their receptors (BRS3, NMBR and GRPR) in chickens
}

\author{
Chunheng Mo*, Long Huang*, Lin Cui, Can Lv, Dongliang Lin, Liang Song, \\ Guoqiang Zhu, Juan Li and Yajun Wang
}

Key Laboratory of Bio-resources and Eco-environment of Ministry of Education, College of Life Sciences, Sichuan University, Chengdu, People's Republic of China

*(C Mo and L Huang contributed equally to this work)
Correspondence should be addressed to $\mathrm{Y}$ Wang or $\mathrm{J} \mathrm{Li}$ Email cdwyjhk@gmail.com or lijuanscuhk@163.com

\begin{abstract}
The two structurally and functionally related peptides, gastrin-releasing peptide (GRP) and neuromedin $\mathrm{B}$ (NMB) play critical roles in many physiological/pathological processes in mammals. However, the information regarding the expression and functionality of avian NMB, GRP and their receptors is limited. Here, we characterized CNMB, CGRP and their receptors (CNMBR, CGRPR and CBRS3) in chickens. Our results showed that: (1) CNMBR and CGRPR expressed in CHO cells could be potently activated by CNMB and CGRP, respectively, as monitored by cell-based luciferase reporter assays, indicating that CNMBR and CGRPR are CNMB- and cGRP-specific receptors; strikingly, BRS3 of chickens (/spotted gars), which is orthologous to mouse bombesin receptor subtype-3 (BRS3), could be potently activated by GRP and NMB, demonstrating that both peptides are the endogenous ligands for chicken (/spotted gar) BRS3; (2) quantitative real-time PCR (qPCR) revealed that $C G R P R$ is widely expressed in chicken tissues with abundant expression in the ovary, pancreas, proventriculus, spinal cord and brain, whereas $C N M B, C N M B R$ and CBRS3 are mainly expressed in the brain and testes; (3) interestingly, qPCR, Western blot and immunostaining revealed that CGRP is predominantly expressed in the anterior pituitary and mainly localized to LH-cells, suggesting that CGRP is likely a novel pituitary hormone in chickens. In summary, our data help to uncover the roles of GRP, NMB and their receptors in birds, and provide the first persuasive evidence from an evolutionary prospective that in vertebrates, GRP and NMB are the endogenous ligands for BRS3, an orphan receptor that has puzzled endocrinologists for more than two decades.
\end{abstract}

Journal of Molecular Endocrinology (2017) 59, 61-79

\section{Introduction}

Bombesin $(\mathrm{BN})$ is a 14-amino acid peptide originally isolated from amphibian skin in 1971 (Erspamer et al. 1970, Anastasi et al. 1971), which has a potent stimulatory action on preparations of intestinal, uterine and urine tract smooth muscle (Erspamer et al. 1972). Subsequently, two structurally and functionally related bombesin-like peptides encoded by separate genes, gastrin-releasing peptide (GRP) and neuromedin B (NMB), have also been identified in mammals (McDonald et al. 1979, Minamino et al. 1983, Spindel et al. 1984, Krane et al. 1988). Two active forms of GRP with an identical C terminus, $\mathrm{GRP}_{27}$ (27 amino acids) and $\mathrm{GRP}_{10}$ (10 amino 
acids), have been isolated in porcine stomach and spinal cord, respectively (McDonald et al. 1979, Minamino et al. 1984). NMB is a 10-amino acid peptide originally isolated from porcine spinal cord (Minamino et al. 1983). Shortly after its discovery, the two N-terminally extended forms of $\mathrm{NMB}$ (designated as $\mathrm{NMB}_{30}$ and $\mathrm{NMB}_{32}$, respectively) have also been identified in porcine brain and spinal cord (Minamino et al. 1985).

In mammals, GRP and NMB are widely expressed in the central nervous system (CNS) and peripheral tissues (Wada et al. 1990, Moody \& Merali 2004), including the gastrointestinal (GI) tract, urogenital and reproductive system, lung and anterior pituitary (Jones et al. 1992, Houben et al. 1993, Jensen et al. 2008). In accordance with their wide distribution, GRP is reported to regulate many physiological/pathological processes including food intake, circadian rhythm, itching, smooth muscle contraction, GI tract motility and cell proliferation in normal tissues and many cancerous tissues (Rozengurt 1988, Merali et al. 1999, McArthur et al. 2000, Sun \& Chen 2007, Jensen et al. 2008, Sun et al. 2009). Like GRP, NMB is also involved in the control of many physiological/pathological processes, such as food intake, thermogenesis, pituitary hormone secretion and cell proliferation of both normal and cancerous tissues (Rettori et al. 1989, Ladenheim et al. 1994, Lach et al. 1995, Matusiak et al. 2005). It is clear that the biological actions of GRP and NMB are mediated by their specific receptors, namely GRP receptor (GRPR) and NMB receptor (NMBR), respectively (Spindel et al. 1990, Battey et al. 1991, Wada et al. 1991, Benya et al. 1995). Both GRPR and NMBR belong to bombesin receptor family of $G$ protein-coupled receptor (GPCR) and are functionally coupled to Gq protein (Benya et al. 1995, Jensen et al. 2008). Upon ligand stimulation, both receptors can trigger multiple signaling pathways, such as calcium mobilization and activation of MAPK/ERK signaling cascade (Jensen et al. 2008). In consistence with the broad spectrum of GRP/NMB actions, GRPR and NMBR are reported to be widely expressed in the CNS and peripheral tissues in mammals (Wada et al. 1992, Sano et al. 2004, Ohki-Hamazaki et al. 2005, Jensen et al. 2008). Apart from GRPR and NMBR, a third bombesin receptor named bombesin receptor subtype-3 (BRS3), which shows high sequence identity to GRPR $(\sim 58 \%)$ and NMBR ( 48\%), has also been identified in mammals (Gorbulev et al. 1992, Fathi et al. 1993). Since BRS3 displays an extremely low affinity to GRP/NMB
$\left(K_{i}>>1000 \mathrm{nM}\right)$ or other naturally occurring bombesinrelated peptides (Gorbulev et al. 1992, Nagalla et al. 1996, Mantey et al. 1997, Ryan et al. 1998), thus, the endogenous ligand of BRS3 has remained an open question and BRS3 has been viewed as an orphan receptor. However, accumulating evidence from BRS3deficient mice has suggested that BRS3 expressed in the CNS may regulate many vital physiological processes, such as energy homeostasis, body temperature, metabolic rates and obesity (Ohki-Hamazaki et al. 1997b, Guan et al. 2010, Metzger et al. 2010).

As in mammals, both GRP and NMB and their putative receptors also exist in non-mammalian vertebrates, including birds, frogs and teleosts (Vaillant et al. 1979, McDonald et al. 1980, Nagalla et al. 1992, Volkoff et al. 2000, Xu \& Volkoff 2009, Yun et al. 2015). Moreover, there are also lines of evidence showing that GRP/NMB play important roles in many physiological processes in nonmammalian vertebrates, such as inhibition of food intake in chickens and teleosts following central or peripheral administration (Tachibana et al. 2010a,b, Schroeter et al. 2015), and regulation of gastric acid secretion, gallbladder motility, crop-emptying rate, pancreatic fluid and protein secretion in chickens or turkeys (Linari \& Linari 1975, Campbell et al. 1991, 1994, Tachibana et al. 2010b, Scanes \& Pierzchala-Koziec 2014). However, in contrast to the extensive studies in mammals, the identity, signaling property and expression of the receptors for GRP and NMB have not been fully characterized in nonmammalian vertebrates including birds (Iwabuchi et al. 2003, Ohki-Hamazaki et al. 2005). Therefore, using chicken as an animal model, our present study aimed to: (1) identify and functionally characterize all the receptors for GRP/NMB; (2) systematically investigate the spatial expression of GRP, NMB and their receptors. As a result, we identified three functional receptors (GRPR, NMBR and BRS3) for chicken GRP/NMB. Strikingly, we demonstrated that both GRP and NMB could potently activate BRS3, suggesting they are both potent ligands of BRS3. Like chicken BRS3, spotted gar BRS3 could be effectively activated by GRP and NMB in vitro. Moreover, we found that GRP is predominantly expressed in chicken anterior pituitaries. Undoubtedly, our study presents the first convincing evidence that GRP and NMB are most likely the endogenous ligands for orphan receptor BRS3 in vertebrates from an evolutionary perspective, and puts forward a new concept that GRP is likely a novel pituitary hormone in an avian species (i.e. chicken). http://jme.endocrinology-journals.org DOI: 10.1530/JME-17-0020
() 2017 Society for Endocrinology Printed in Great Britain
Published by Bioscientifica Ltd 


\section{Materials and methods}

\section{Chemicals, hormones, antibodies and primers}

Chicken $\mathrm{GRP}_{27}\left(\mathrm{cGRP}_{27}\right), \mathrm{GRP}_{10}\left(\mathrm{cGRP}_{10}\right)$ and NMB (cNMB) were synthesized using solid-phase Fmoc chemistry (GL Biochem, Shanghai, China). Goat antiGRP polyclonal antibody was purchased from Santa Cruz Biotechnology and monoclonal antibody for $\beta$-actin was obtained from Cell Signaling Technology. Anti-ACTH antibody was purchased from Abcam. Donkey anti-goat IgG $(\mathrm{H}+\mathrm{L})$ cross-adsorbed secondary antibody (DyLight 488 conjugate) and anti-rabbit $\operatorname{IgG}(\mathrm{H}+\mathrm{L})$ cross-adsorbed secondary antibody (Dylight 550 conjugate) were purchased from Thermo Fisher Scientific. The polyclonal antibodies against recombinant full-length chicken $\mathrm{GH}$, PRL and LH $\beta$ were prepared in our laboratory (Huang et al. 2014, Meng et al. 2014, Bu et al. 2016). All primers were synthesized by Beijing Genome Institute (BGI, China) and listed in Supplementary Table 1 (see section on supplementary data given at the end of this article).

\section{Total RNA extraction}

Adult chickens (1-year-old) of both sexes (Lohmann layer) were purchased from local commercial company. Chickens were killed, and various tissues including the different brain regions were isolated and collected for RNA extraction. Total RNA was prepared using RNAzol (Molecular Research Center, Cincinnati, OH, USA) according to the manufacturer's instructions. All experiments were performed according to the guidelines provided by the Animal Ethics Committee of Sichuan University.

\section{Reverse transcription and quantitative real-time PCR (qPCR)}

Two micrograms of total RNA and $0.5 \mu \mathrm{g}$ of oligodeoxythymide were mixed in a total volume of $5 \mu \mathrm{L}$, incubated at $70^{\circ} \mathrm{C}$ for $10 \mathrm{~min}$ and cooled at $4^{\circ} \mathrm{C}$ for $2 \mathrm{~min}$. The first strand buffer, $0.5 \mathrm{mM}$ each deoxynucleotide triphosphate and $100 \mathrm{U}$ Moloney murine leukemia virus (MMLV) reverse transcriptase (Takara) were then added into the reaction mix in a total volume of $10 \mu \mathrm{L}$. Reverse transcription (RT) was performed at $42^{\circ} \mathrm{C}$ for $90 \mathrm{~min}$.

According to our previously established method (Cai et al. 2015), quantitative real-time PCR was conducted on the CFX96 Real-time PCR Detection System (Bio-Rad) to examine the mRNA levels of target genes in chicken tissues.

\section{Cloning the cDNAs of chicken GRPR, NMBR and BRS3}

According to the genomic sequences of $c G R P R, c N M B R$ and cBRS3 (http://www.ensembl.org/Gallus_gallus), gene-specific primers were designed to amplify the cDNA containing the open reading frame (ORF) of the receptors from the chicken brain with the use of high-fidelity Taq DNA polymerase (TOYOBO). The amplified PCR products were cloned into pTA2 vector and sequenced by ABI3100 Genetic Analyzer (BGI). Finally, the cDNA sequence of each receptor was determined by sequencing three independent clones.

\section{Functional characterization of cNMBR, cGRPR and chicken/spotted gar/mouse BRS3 in CHO cells}

Based on the cDNA sequences of chicken GRPR, NMBR and BRS3-like genes, gene-specific primers were used to amplify the ORF from adult chicken brain using highfidelity Taq DNA polymerase (TOYOBO, Japan). The amplified PCR products were cloned into the pcDNA3.1 (+) expression vector (Invitrogen) and sequenced. To compare the functional difference of chicken BRS3 with BRS3 from other vertebrate species, including mouse and spotted gar, we also amplified the complete coding regions of mouse and spotted gar BRS3 from brain tissues and cloned them into the pcDNA3.1 (+) expression vector.

According to our previously established methods, the functionality and signaling property of each receptor was examined in Chinese hamster ovary (CHO) cells using pGL3-NFAT-RE-luciferase reporter system (Wang et al. 2012), pGL4-SRE-luciferase reporter system (Mo et al. 2015) and pGL3-CRE-luciferase reporter system (Wang et al. 2007a).

\section{Western blot}

To compare the protein level of cGRP in the anterior pituitary, brain and proventriculus of adult chickens, Western blot analysis was performed. The respective tissue lysates were prepared for the detection of cGRP level using corresponding antibodies (1:300), as described in our recent study (Mo et al. 2015). In parallel, $\beta$-actin level was examined in tissue lysates as a loading control.

To test whether cBRS3 activation can enhance ERK1/2 (44/42 kDa) and CREB (43 kDa) phosphorylation, HEK293 cells that transiently expressed cBRS3 were treated by $\mathrm{CGRP}_{27}(100 \mathrm{nM})$ for $10 \mathrm{~min}$, and the phosphorylated ERK1/2 and CREB levels in cellular lysates were examined by Western blot, as described in our recent study

Published by Bioscientifica Ltd. 
(He et al. 2016, Cui et al. 2017). $\beta$-actin level was also examined and used as a loading control.

\section{Detection of GRP mRNA and protein expression in chicken anterior pituitaries}

To examine the spatial distribution of GRP in chicken anterior pituitaries, qPCR, Western blot and immunohistochemical staining (IHC) were used in this experiment, as described in our recent studies (Meng et al. 2014, Mo et al. 2015). In brief, anterior pituitaries collected from adult female chickens were washed with PBS to remove any contaminating blood cells. The cephalic lobe and caudal lobe were separated carefully by scalpels, and their respective tissue lysates and total RNA were prepared for Western blot detection of cGRP (or $c G H / \beta$-actin) protein expression and $\mathrm{qPCR}$ assay of cGRP mRNA expression, respectively. For IHC, anterior pituitaries from adult female chickens were fixed in $4 \%$ paraformaldehyde, paraffinized and sliced into sections. IHC staining was performed in the pituitary sections using a Streptavidin-Biotin-Peroxidase Complex (SABC) kit (Boster Biological Technology Ltd) according to the manufacturer's instructions. Goat anti-GRP antibody (1:300) was used to probe the spatial distribution of cGRP in chicken pituitaries. Pituitary sections incubated with $\mathrm{cGRP}_{27}$-preabsorbed GRP antibody (incubated overnight at $4^{\circ} \mathrm{C}$ with $100 \mathrm{ng} / \mathrm{mL}$ of $\mathrm{cGRP}_{27}$ ) was used as a negative control in parallel.

\section{Double fluorescence staining}

The dispersed anterior pituitary cells from adult female chickens were cultured in Medium 199 supplemented with $15 \%$ fetal bovine serum (Invitrogen) in a Corning Cell-BIND 96-well plates (Corning) at $37^{\circ} \mathrm{C}$ with $5 \%$ $\mathrm{CO}_{2}$ at a density of $1 \times 10^{4}$ cells/well, as described in our previous study (Meng et al. 2014). After $4 \mathrm{~h}$ of culture, the pituitary cells were fixed in $4 \%$ paraformaldehyde and washed with PBS. Then, the cells were treated by $0.1 \%$ Triton X-100 for $10 \mathrm{~min}$, washed with PBS and incubated with the blocking buffer (1\% BSA in PBS) for $30 \mathrm{~min}$ at room temperature to minimize non-specific adsorption. After blocking, the two primary antibodies, goat anti-GRP and rabbit anti-cGH (or anti-cPRL/-cLH $\beta /$-ACTH) diluted in blocking buffer (1:500 or 1:1000), were added to each well and incubated at $4^{\circ} \mathrm{C}$ overnight. The cells were washed and incubated with fluorochrome-conjugated secondary antibodies (1:300) for $1 \mathrm{~h}$ at room temperature. Finally, the pituitary cells were counterstained with DAPI and observed under a fluorescence microscope (Nikon ECLIPSE Ti).

\section{Data analysis}

The mRNA level of target gene was normalized by that of $\beta$-actin and then expressed as fold difference compared to chosen tissue. The luciferase activities of $\mathrm{CHO}$ cells expressing GRPR/NMBR/BRS3 in peptide treatment group were expressed as relative fold increase compared to the control group (without peptide treatment). The data were analyzed by one-way ANOVA followed by Dunnett's test. The dose-responsive curves were constructed using nonlinear regression models, and the corresponding half-maximal effective concentration $\left(\mathrm{EC}_{50}\right)$ values were evaluated with GraphPad Prism 5 (GraphPad Software). All experiments were repeated at least twice to validate our results.

\section{Results}

\section{Cloning of NMBR CDNA and identification of BRS3 in chickens}

Although NMBR is predicted to exist in chickens and other lower vertebrates, NMBR cDNA has not been reported in any non-mammalian vertebrates. In this study, we cloned the cDNA containing an ORF of NMBR from the chicken brain (Supplementary Fig. 1). The cloned $c N M B R$ cDNA is predicted to encode a receptor of 388 amino acids (accession no.: KU887757), which shows high amino acid sequence identities with NMBR of mice (72\%), Xenopus tropicalis (82\%), Nile tilapia (68\%) and spotted gars (74\%). Like human NMBR, cNMBR contains seven transmembrane domains (TMD1-7), a DRY motif critical for $G$ protein coupling, and two cysteines for disulfide bond formation (Fig. 1). Moreover, cNMBR shows high amino acid sequence identities with chicken GRPR (53\%) and BRS3 (48\%).

Although BRS3 exists in mammals, it remains uncertain whether BRS3 exists in chickens. Using synteny analysis, we found that BRS3 exists in chickens and is located on chromosome 4 , which differs from the chromosomal location of $N M B R$ and GRPR (Fig. 2). Interestingly, we noted that chicken $B R S 3$ is identical to a previously reported 'bombesin receptor subtype-3.5 (BRS3.5)' (Iwabuchi et al. 2003), and thus, we designated this BRS3.5 as BRS3 in this study.

As in chickens, BRS3 also exists in other nonmammalian vertebrates including western painted turtles,

Published by Bioscientifica Ltd. 

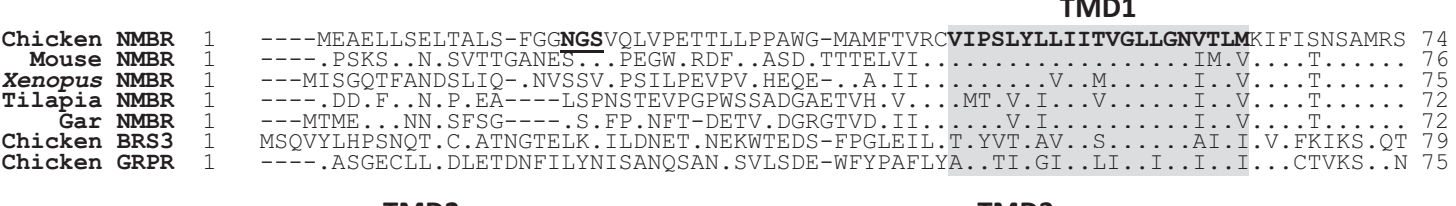

TMD2

TMD3
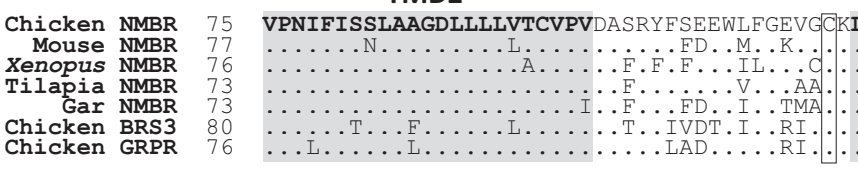

TMD4

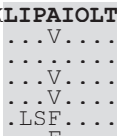

SVGVSVFTLTALSADRYKAIVKPMDIQTSSA

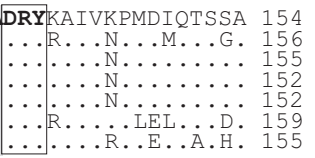

chicken NMBR Mouse NMBR Tilapia NMBR Gar NMBR Chicken BRS3

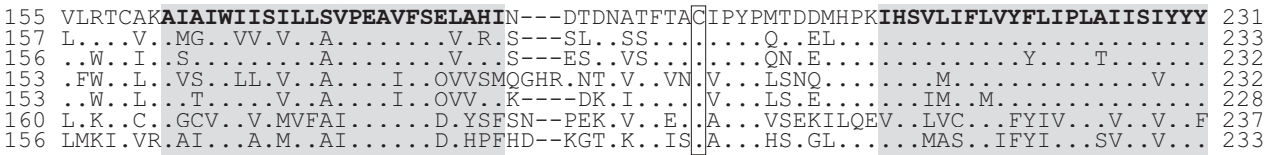

TMD6
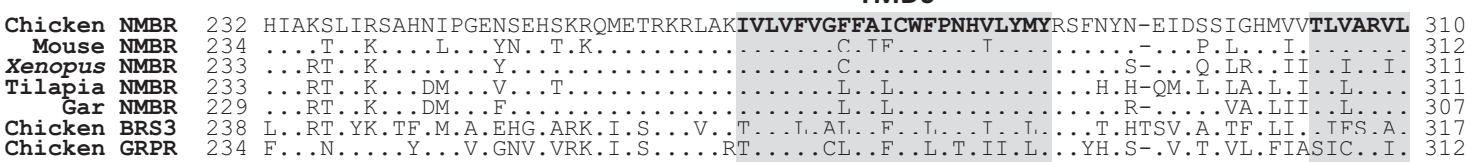

TMD7

Chicken NMBR

Xenopus NMBR

Tilapia NMBR

Chicken BRS

Chicken GRPR

SFCNSCVNPFALYLLSESFRRHFNNQLRCRKKPQQERSASYLRNSSAIQTTSLKSNTRNTVTSVTOLNGHNLKOEMSS- 388

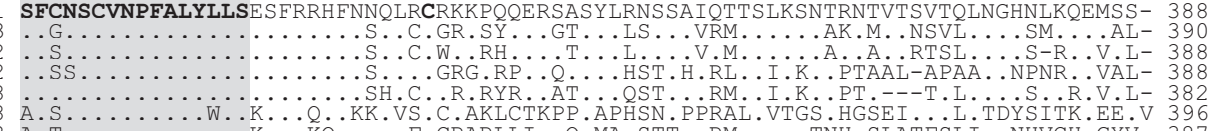

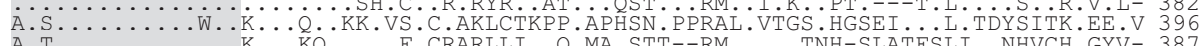

A.T.................. CRARLLI..Q.MA.STT--RM. ...TNH-SLATESLI. NHVCH.GYV- 387

\section{Figure 1}

Amino acid alignment of chicken NMBR (KU887757) with that of mice (NP_032729), Xenopus tropicalis (XP_012818691), Nile tilapia (XP_005452510) and spotted gars (XP_006643031), or with chicken BRS3 (NP_989737) and GRPR (NP_989738). The conserved 'DRY motif' is boxed and the seven transmembrane domains (TMD1-7) are shaded; the potential $N$-glycosylation site (NXT/S) is underlined; the pair of cysteine residues proposed for disulfide bond formation are boxed; dots indicate amino acids identical to chicken NMBR; dashes denote gaps in the alignment.

Xenopus tropicalis and spotted gars (Fig. 2). Interestingly, $B R S 3$ is likely lost in teleosts (e.g. Nile tilapia), as revealed by synteny analysis. In addition, some of the paralogous genes adjacent to $B R S 3 / N M B R / G R P R$ (e.g. $A D G R G 2 / 4 / 6$ ) could be identified in these vertebrate species examined, implicating that BRS3, GRPR and NMBR were likely duplicated from a common ancestral gene by the 2 rounds of genome duplication (2R) occurred during early vertebrate evolution (Fig. 2) (Yun et al. 2015). Using RT-PCR, we cloned the cDNA of spotted gar BRS3 from brain tissue (KX447669) (Supplementary Figs 2 and 3). This finding further indicates the presence and expression of $B R S 3$ in lower vertebrate species.

\section{Functional characterization of chicken NMBR, BRS3 and GRPR}

To compare the functional difference between the three chicken bombesin receptors (cNMBR, cGRPR and cBRS3), each receptor was transiently expressed in $\mathrm{CHO}$ cells and treated by chicken $\mathrm{GRP}_{27}, \mathrm{GRP}_{10}$ and $\mathrm{NMB}_{10}$ (Fig. 3).
Receptor activation was then examined by pGL3-NFATRE-lcuiferase reporter, pGL4-SRE-luciferase reporter and pGL3-CRE-luciferease reporter systems, which could monitor receptor-activated calcium mobilization (Wang et al. 2012), MAPK/ERK (Mo et al. 2015) and adenylate cyclase (AC)/cAMP/PKA signaling pathways (Wang et al. 2007a), respectively.

Using the pGL3-NFAT-RE-luciferase reporter system, we demonstrated that cNMB could potently activate cNMBR expressed in CHO cells ( $\left.\mathrm{EC}_{50}: 8.2 \mathrm{nM}\right)$. On the other hand, $\mathrm{CGRP}_{27}$ and $\mathrm{cGRP}_{10}$ are much less potent, indicating that CNMBR is a NMB-specific receptor. By contrast, cGRPR could be potently activated by $\mathrm{CGRP}_{27}$ and cGRP 10 (with $\mathrm{CGRP}_{27}$ being slightly more potent than $\mathrm{CGRP}_{10}$ ), while $\mathrm{CNMB}_{10}$ is ineffective. These findings indicate that GRPR is a GRP-specific receptor. Strikingly, we found that cBRS3 could be effectively activated by the three peptides $\left(\mathrm{EC}_{50}\right.$ of $\mathrm{cGRP}_{27}: 8.3 \mathrm{nM} ; \mathrm{EC}_{50}$ of $\mathrm{cGRP}_{10}: 9.7 \mathrm{nM} ; \mathrm{EC}_{50}$ of cNMB: $28.2 \mathrm{nM}$ ) (Fig. 3). This finding indicates that cBRS3 can function as a receptor common for both cGRP and $\mathrm{CNMB}$, and display a weak selectivity toward cGRP http://jme.endocrinology-journals.org DOI: 10.1530/JME-17-0020
๑ 2017 Society for Endocrinology Printed in Great Britain
Published by Bioscientifica Ltd. 
A

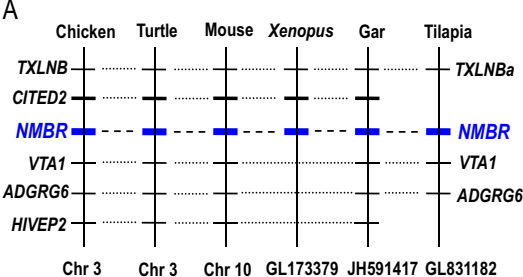

C

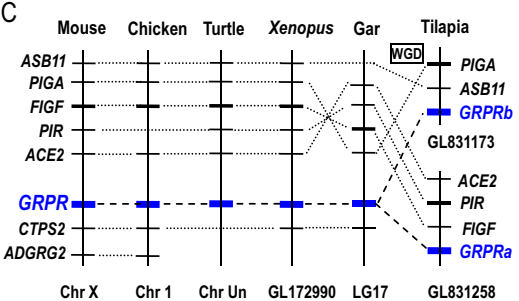

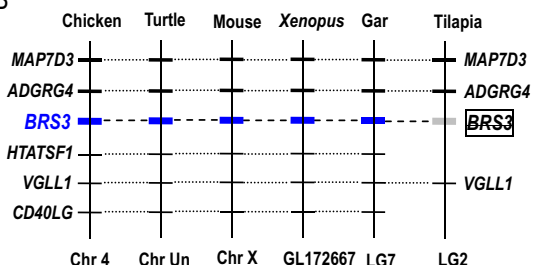

D

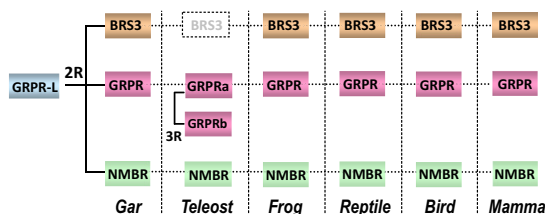

Figure 2

(A, B and C) Synteny analysis showing that NMBR (A), BRS3 (B) and GRPR (C) are located in distinct syntenic regions conserved between chickens, western painted turtles, mice, Xenopus tropicalis, spotted gars and Nile tilapia. The two copies of GRPR (GRPRa and GRPRb) identified in Nile tilapia are likely to be paralogs generated by the third round (3R) of teleost-specific genome duplication (WGD) event (Meyer \& Van de Peer 2005), while $B R S 3$ is likely lost. Dashed lines denote the genes of interest, while dotted lines indicate the syntenic genes identified in these species. Genes were labeled based on their gene symbols in the human genome. Chr, chromosome; Chr Un, chromosome unknown. (D) Schematic diagram showing the existence of $B R S 3, G R P R$ and NMBR in spotted gars, teleosts (e.g. Nile tilapia, BRS3 is lost), frogs (e.g. Xenopus tropicalis), reptiles (e.g. western painted turtles), birds (e.g. chickens) and mammals (e.g. mice), which were likely duplicated from an ancestral GRPR-like gene (GRPR-L) by the two rounds (2R) of genome duplication event during vertebrate evolution (Yun et al. 2015).
(Table 1). Furthermore, our findings also suggest that as in mammals, activation of all three receptors may cause calcium mobilization in chickens (Jensen et al. 2008).

Using pGL4-SRE-luciferase reporter system, we also demonstrated that cNMBR expressed in $\mathrm{CHO}$ cells could be potently activated by cNMB ( $\left.\mathrm{EC}_{50}, 5.8 \mathrm{nM}\right)$, but not by cGRP, also supporting that cNMBR is a NMBspecific receptor (Fig. 4). By contrast, both $\mathrm{CGRP}_{27}$ and $\mathrm{cGRP}_{10}$ (and not $\mathrm{cNMB}_{10}$ ) could potently activate cGRPR expressed in $\mathrm{CHO}$ cells, further supporting the notion
A

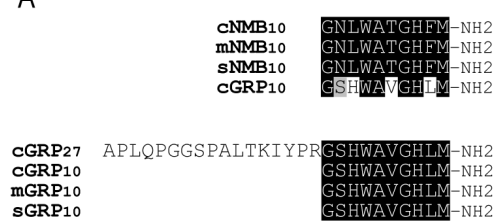

MGRP10
B
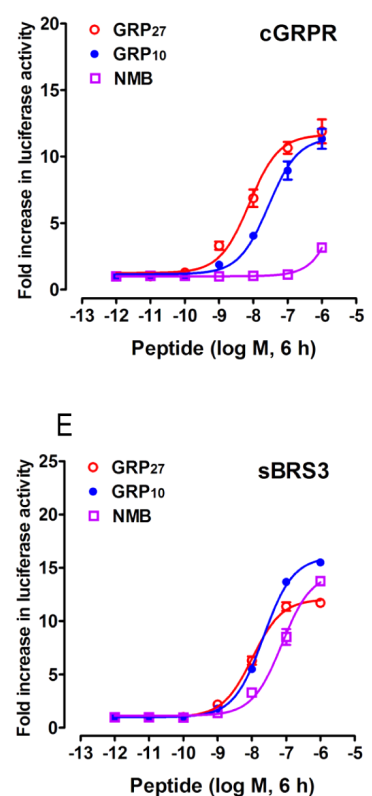

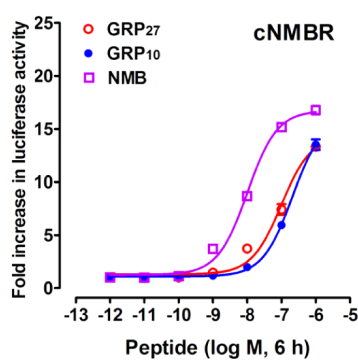

$\mathrm{F}$

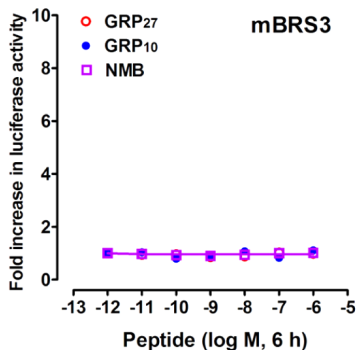

D

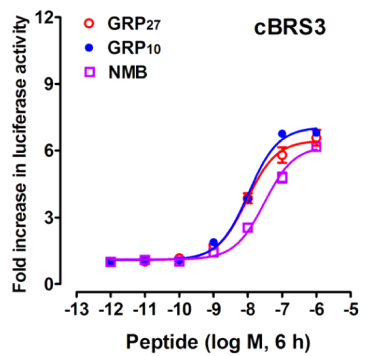

G

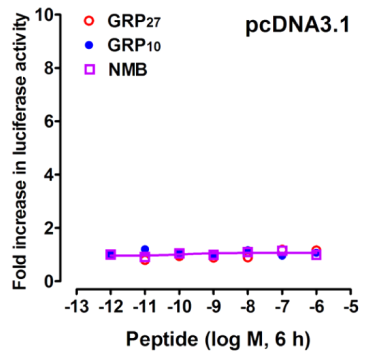

Figure 3

(A) Amino acid sequence alignment of chicken NMB ( $\left.\mathrm{cNMB}_{10}\right)$ or GRP (cGRP 27 and $\left.\mathrm{CGRP}_{10}\right)$ with NMB/GRP from mouse $\left(\mathrm{mNMB}_{10} / \mathrm{mGRP}_{10}\right)$ and spotted gar $\left(\mathrm{sNMB}_{10} / \mathrm{sGRP} 10\right) ;\left(\mathrm{B}, \mathrm{C}, \mathrm{D}, \mathrm{E}\right.$ and F) effects of $\mathrm{cGRP}_{27}, \mathrm{CGRP}_{10}$ and $\mathrm{cNMB}_{10}$ on activating chicken (c-) GRPR (B), cNMBR (C), cBRS3 (D), spotted gar BRS3 (sBRS3) (E), and mouse BRS3 (mBRS3) (F) expressed in CHO cells, monitored by pGL3-NFAT-RE-luciferase reporter system; (G) cells co-transfected with the empty pcDNA3.1 (+) vector and pGL3-NFAT-RE-luciferase reporter construct were used as internal controls, and peptide treatment did not alter the luciferase activity of $\mathrm{CHO}$ cells at any concentration tested. Each data point represents mean \pm S.E.M. of four replicates $(N=4)$. 
Table $1 \mathrm{EC}_{50}$ values of $\mathrm{CGRP}$ and $\mathrm{CNMB}$ in activating different signaling pathways in $\mathrm{CHO}$ cells expressing chicken (c-) GRPR/ NMBR/BRS3 or spotted gar (s-)/mouse (m-) BRS3.

\begin{tabular}{|c|c|c|c|c|c|}
\hline \multicolumn{6}{|c|}{$\mathrm{EC}_{50}$ values $(\mathrm{nM})$} \\
\hline Peptide & cGRPR & cNMBR & cBRS3 & sBRS3 & mBRS3 \\
\hline \multicolumn{6}{|c|}{ Calcium signaling pathway } \\
\hline $\mathrm{CGRP}_{27}$ & 3.4 & $>200^{a}$ & 8.3 & 9.2 & - \\
\hline $\mathrm{CGRP}_{10}$ & 15.7 & $>200^{a}$ & 9.7 & 17.9 & - \\
\hline cNMB & - & 8.2 & 28.2 & 44 & - \\
\hline \multicolumn{6}{|c|}{ MAPK/ERK signaling pathway } \\
\hline $\mathrm{CGRP}_{27}$ & 6.1 & $\sim 100^{a}$ & 7.5 & 4.6 & - \\
\hline $\mathrm{CGRP}_{10}$ & 16.9 & $>100^{a}$ & 8.4 & 5.9 & - \\
\hline cNMB & $>100^{a}$ & 5.8 & 28.3 & 30.8 & - \\
\hline \multicolumn{6}{|c|}{ CAMP/PKA signaling pathway } \\
\hline $\mathrm{cGRP}_{27}$ & 66.8 & $>200^{a}$ & 41.8 & 35.9 & - \\
\hline $\mathrm{CGRP}_{10}$ & $>100^{a}$ & $>200^{a}$ & 71 & 42.2 & - \\
\hline cNMB & - & 23.3 & $>200^{a}$ & 125.4 & - \\
\hline
\end{tabular}

' - ' means that the $\mathrm{EC}_{50}$ values could not be calculated based on the experimental data.

alndicates that $\mathrm{EC}_{50}$ value was roughly estimated based on the experimental data. that GRPR is a GRP-specific receptor. In contrast, cBRS3 could be effectively activated by all three peptides tested $\left(\mathrm{EC}_{50}\right.$ of $\mathrm{cGRP}_{27}: 7.5 \mathrm{nM} ; \mathrm{EC}_{50}$ of $\mathrm{cGRP}_{10}: 8.4 \mathrm{nM} ; \mathrm{EC}_{50}$ of cNMB: $28.3 \mathrm{nM}$ ) and it shows a weak selectivity toward GRP (Fig. 4) (Table 1). This finding substantiates the idea that cBRS3 can function as a receptor common for both cGRP and cNMB. Meanwhile, our findings also suggest the functional coupling of the three receptors to the MAPK/ ERK signaling cascade.

Using the pGL3-CRE-luciferease system, cGRPR and cNMBR were also shown to be preferentially activated by cGRP and cNMB, respectively, while cBRS3 was activated by both GRP and NMB with similar potencies (Fig. 5). This finding suggests that all three receptors are also coupled to AC/cAMP/PKA pathway. However, we noted that much higher concentrations of $\mathrm{CGRP} / \mathrm{CNMB}$ are required to activate the AC/cAMP/PKA signaling pathway than the other two pathways tested (Table 1).

To further verify the functional coupling of cGRPR, cNMBR and cBRS3 to the calcium mobilization, MAPK/ERK
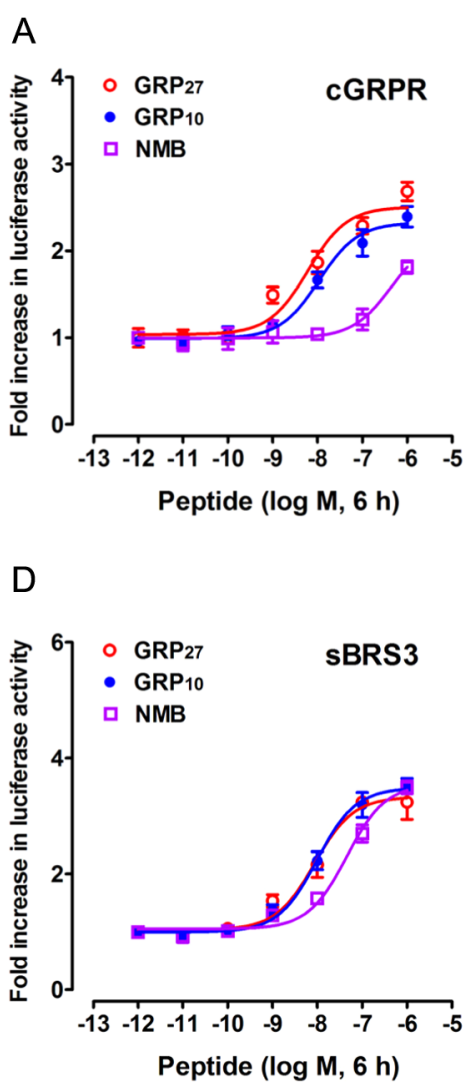

$B$

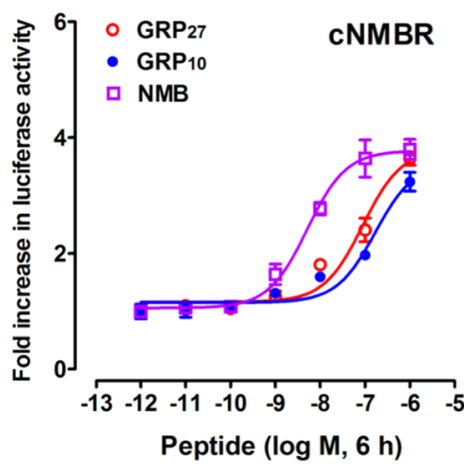

$E$

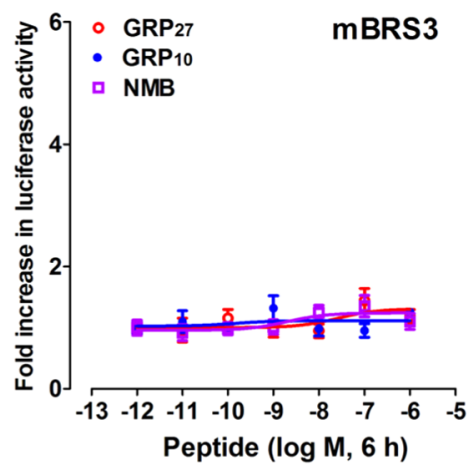

C

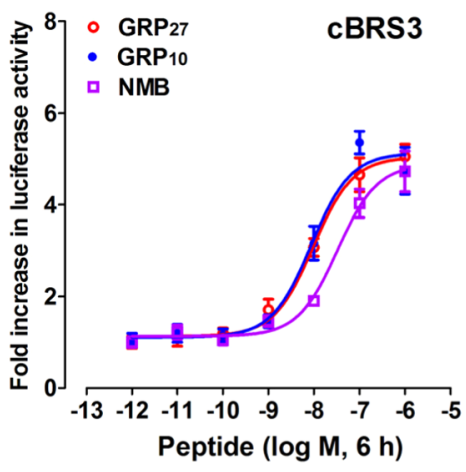

F

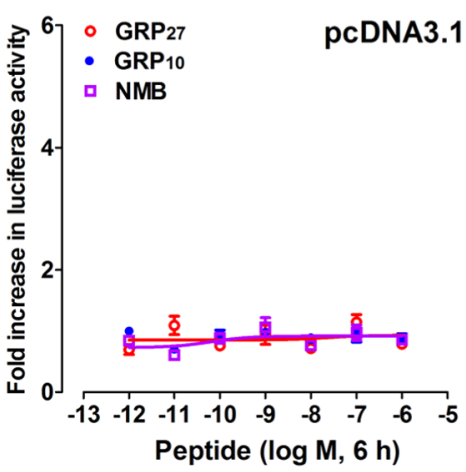

Figure 4

$\left(A, B, C, D\right.$ and E) Effects of $\mathrm{CGRP}_{27}, \mathrm{CGRP}_{10}$ and $\mathrm{CNMB}_{10}$ on activating chicken (c-) GRPR (A), CNMBR (B), cBRS3 (C), spotted gar BRS3 (sBRS3) (D) and mouse BRS3 (mBRS3) (E) expressed in CHO cells, monitored by pGL4-SRE-luciferase reporter system; (F) CHO cells co-transfected with empty pcDNA3.1 (+) vector and pGL4-SRE-luciferase reporter construct were used as internal controls, and peptide treatment did not alter the luciferase activity of CHO cells at any concentration tested. Each data point represents mean \pm S.E.M. of four replicates $(N=4)$.

http://jme.endocrinology-journals.org DOI: 10.1530/JME-17-0020
C 2017 Society for Endocrinology Printed in Great Britain
Published by Bioscientifica Ltd 
A

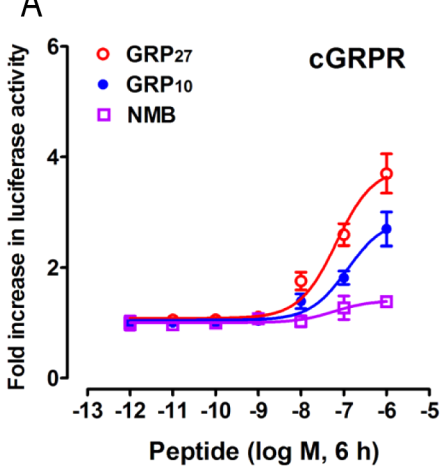

D

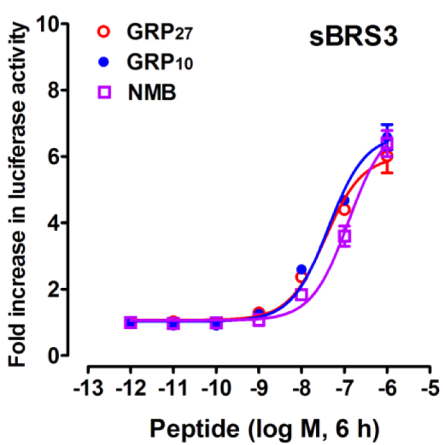

B

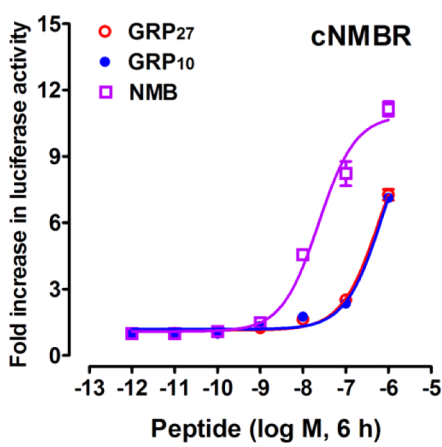

$E$

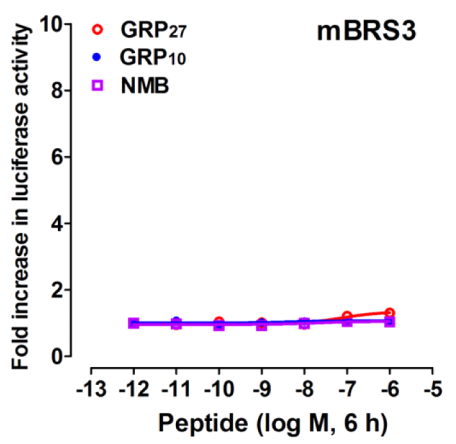

C

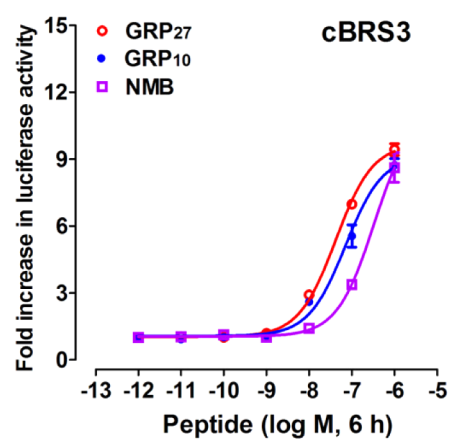

$\mathrm{F}$

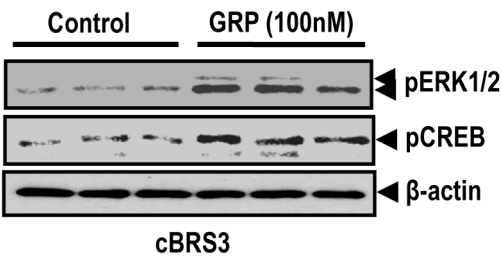

Figure $\mathbf{5}$

(A, B, C, D and E) Effects of $\mathrm{CGRP}_{27}, \mathrm{CGRP}_{10}$ and $\mathrm{CNMB}_{10}$ on activating chicken (c-) GRPR (A), cNMBR (B), cBRS3 (C), spotted gar BRS3 (sBRS3) (D) and mouse BRS3 (mBRS3) (E) expressed in CHO cells, monitored by pGL3-CRE-luciferase reporter system. CHO cells co-transfected with empty pcDNA3.1 (+) vector and pGL3-CRE-luciferase reporter construct were used as internal controls, and peptide treatment did not alter the luciferase activity of CHO cells at any concentration tested (data not shown). Each data point represents mean \pm S.E.M. of four replicates $(N=4)$. $(F)$ Western blot showing that cGRP ${ }_{27}$ treatment (100 nM, $10 \mathrm{~min}$ ) can enhance the phosphorylation levels of ERK1/2 (pERK1/2) and CREB (pCREB) in HEK293 cells expressing chicken BRS3 (cBRS3).

and AC/cAMP/PKA signaling pathways, pharmacological drugs targeting these signaling pathways, such as $2-\mathrm{APB}$ (an inhibitor of IP3 receptor, which blocks IP3-induced calcium mobilization from the endoplasmic reticulum), PD98059 (an inhibitor of the MEK/ERK signaling cascade), MDL12330A (an AC inhibitor) and H89 (a PKA inhibitor) were used to test whether they can inhibit receptoractivated signaling pathways. As shown in Fig. 6, all drugs tested could inhibit GRP-induced luciferase activity of CHO cells expressing cGRPR, cNMBR or cBRS3. Moreover, U73122, a phospholipase C (PLC) inhibitor, could inhibit the receptor-activated MAPK/ERK signaling pathway, suggesting that the three receptors require PLC to activate downstream MAPK/ERK signaling cascade (Fig. 6).

Using Western blot, we demonstrated that the activation of cBRS3 transiently expressed in HEK293 cells by CGRP $_{27}$ treatment could enhance ERK1/2 (44/42 kDa) and CREB (43 kDa) phosphorylation, further confirming the functional coupling of cBRS3 to both MAPK/ERK and AC/cAMP/PKA/CREB pathways (Fig. 5). Similarly, CNMBR and cGRPR activation can also enhance the phosphorylation of ERK1/2 and CREB in vitro (data not shown).

\section{Functional characterization of spotted gar and mouse BRS3}

The high potency of GRP and NMB in activating chicken BRS3 led us to test whether GRP/NMB could activate BRS3 from other lower vertebrate species such as spotted gar (a primitive freshwater fish). Using the same approach, we found that like cBRS3, spotted gar BRS3 expressed in $\mathrm{CHO}$ cells could be effectively activated by cGRP ( $\mathrm{CGRP}_{27} /$ $\mathrm{CGRP}_{10}$ ) and $\mathrm{CNMB}$ (with cGRP being slightly more potent than $\mathrm{CNMB}$ ), as monitored by the three luciferase reporter systems. In contrast, mouse BRS3 could neither be activated by cGRP nor by cNMB at any concentration tested (10-12 to $\left.10^{-6} \mathrm{M}\right)$ (Figs 3, 4, 5 and Table 1 ). http://jme.endocrinology-journals.org DOI: 10.1530/JME-17-0020
() 2017 Society for Endocrinology Printed in Great Britain
Published by Bioscientifica Ltd. 
A
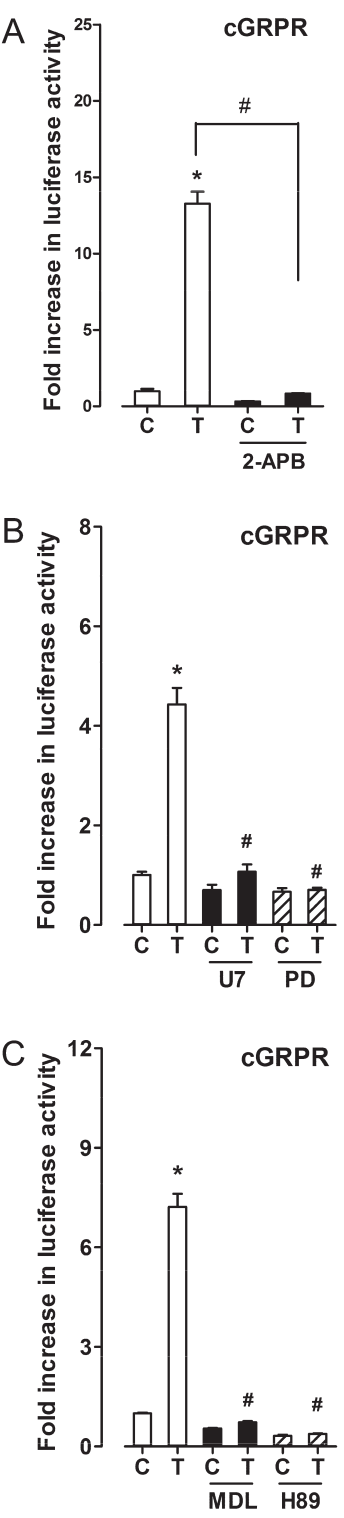
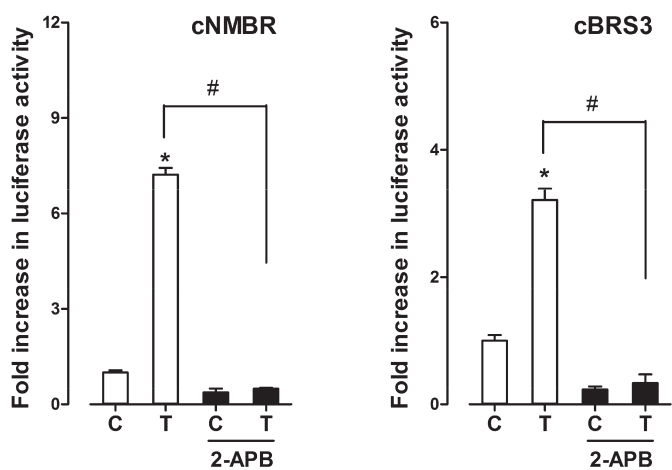

Tissue expression of NMBR, GRPR, BRS3, GRP and NMB in adult chickens

Using qPCR, we examined the mRNA expression of $c N M B, c N M B R, c G R P, c G R P R$ and $c B R S 3$ in adult chicken tissues, including the anterior pituitary, heart, kidneys, liver, lung, muscle, ovary, testes, spleen, pancreas, subcutaneous fat, skin, spinal cord, different brain regions (telencephalon, midbrain, cerebellum, hindbrain and hypothalamus) and various parts of gastrointestinal tract (crop, proventriculus, gizzard, duodenum, jejunum, ileum, cecum and colon).

As shown in Fig. 7, $c N M B R$ is highly expressed in the testes and weakly expressed in the duodenum, colon, kidneys, spinal cord and various brain regions including the hypothalamus. Like $c N M B R, c N M B$ is highly expressed

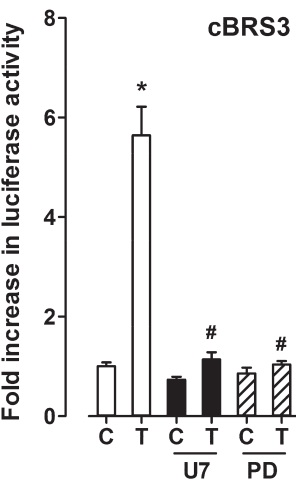

Figure 6

(A) Effects of 2-APB $(100 \mu \mathrm{M})$ on cGRP

(10 nM, 6h)-induced luciferase activity of $\mathrm{CHO}$ cells expressing cGRPR, cNMBR or CBRS3, monitored by pGL3-NFAT-RE-luciferase reporter system; (B) effects of U73122 (U7, $20 \mu \mathrm{M})$ and PD98059 (PD, $100 \mu \mathrm{M})$ on $\mathrm{CGRP}_{27}(10 \mathrm{nM}$, $6 \mathrm{~h}$ )-induced luciferase activity of $\mathrm{CHO}$ cells expressing CGRPR, CNMBR or CBRS3, monitored by pGL4-SRE-luciferase reporter system; (C) effects of MDL12330A (MDL, $20 \mu \mathrm{M})$ and $\mathrm{H} 89(10 \mu \mathrm{M})$ on $\mathrm{CGRP}_{27}(100 \mathrm{nM}, 6 \mathrm{~h})$-induced luciferase activity of $\mathrm{CHO}$ cells expressing cGRPR, CNMBR or CBRS3, monitored by pGL3-CRE-luciferase reporter system. Each drug was added $1 \mathrm{~h}$ before cGRP treatment. In each graph, ' $T$ ' represents peptide treatment and ' $\mathrm{C}$ ' represents control without peptide treatment. Each data point represents mean \pm S.E.M. of four replicates $(N=4)$. ${ }^{*} P<0.01$ vs control (in the absence of drug); $\# P<0.01$ vs peptide treatment (in the absence of drug).

in the testes. In addition, $c N M B$ is moderately expressed in the hypothalamus and ovary, and weakly in other tissues examined, except the kidneys, liver, lung and muscle.

CGRPR is widely expressed in nearly all tissues examined except kidneys and fat. It is highly expressed in the ovary, many brain regions (hypothalamus, midbrain and hindbrain), spinal cord, proventriculus and pancreas, and weakly expressed in other tissues examined.

Strikingly, unlike $c G R P R, c G R P$ is predominantly and abundantly expressed in the anterior pituitary and weakly expressed in most of the tissues examined. The mRNA level of GRP in the anterior pituitary is, at least, a 100-fold higher than that in other tissues examined including the proventriculus. Within the CNS, a relatively high mRNA level of $c G R P$ was detected in the spinal

Published by Bioscientifica Ltd 

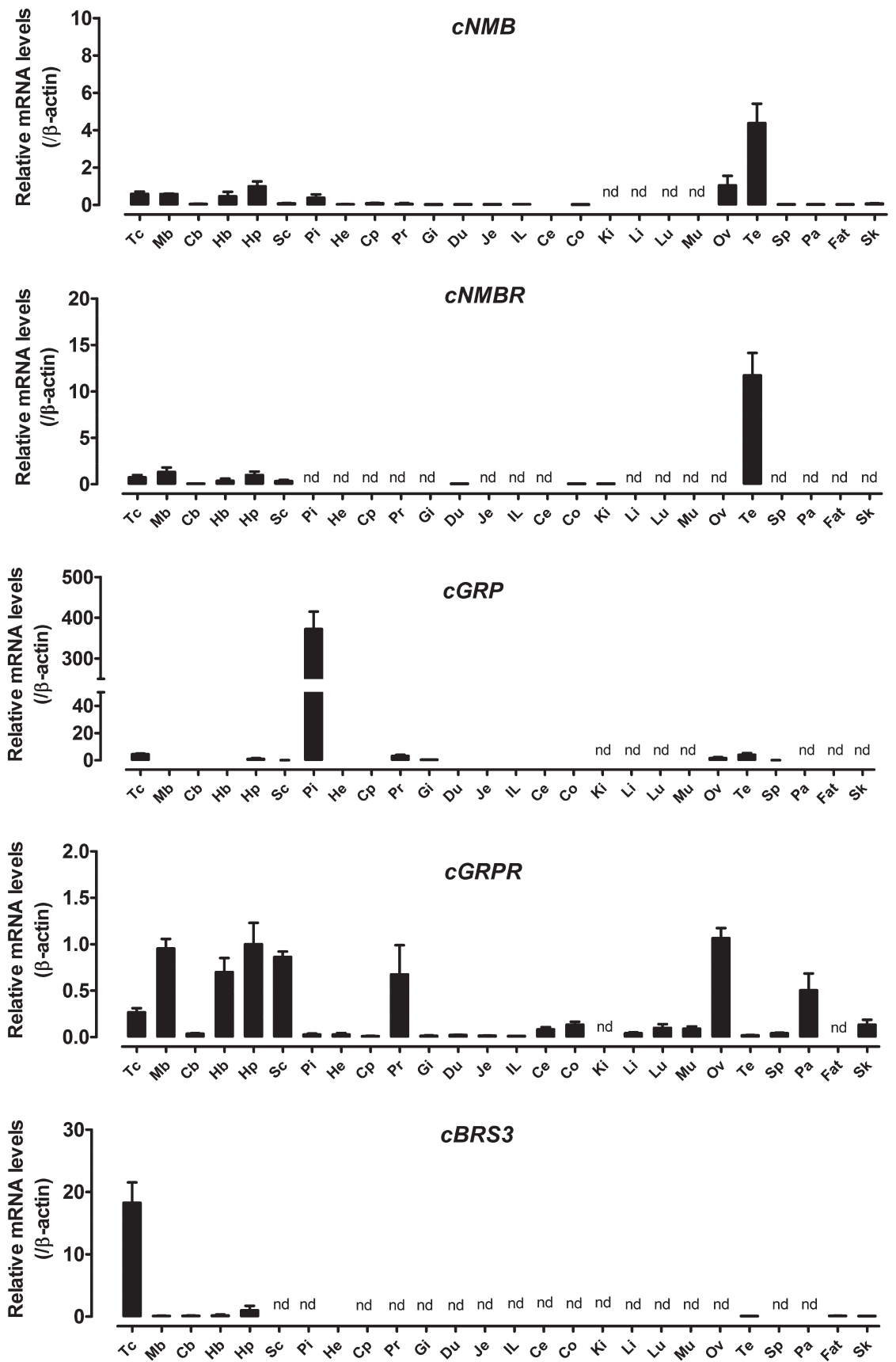

\begin{abstract}
Figure 7
Quantitative real-time PCR assay of $C N M B$, $C N M B R, C G R P, C G R P R$ and $C B R S 3$ mRNA expression in adult chicken tissues, including the telencephalon (Tc), midbrain (Mb), cerebellum $(\mathrm{Cb})$, hindbrain $(\mathrm{Hb})$, hypothalamus $(\mathrm{Hp})$, spinal cord $(\mathrm{Sc})$, anterior pituitary $(\mathrm{Pi})$, heart $(\mathrm{He})$, crop $(\mathrm{Cp})$, proventriculus $(\mathrm{Pr})$, gizzards $(\mathrm{Gi})$, duodenum (Du), Jejunum (Je), ileum (IL), cecum (Ce), colon (Co), kidneys (Ki), liver (Li), lung (Lu), muscle (Mu), ovary (Ov), testes (Te), spleen (Sp), pancreas (Pa), subcutaneous fat (Fat) and skin (Sk). The mRNA levels of each gene were normalized to that of $\beta$-actin and expressed as the fold difference compared with that of hypothalamus (Hp). 'nd' indicates that mRNA of target gene is undetectable. Each data point represents the mean \pm s.E.M. of 6 adult chickens $(N=6)$ (3 males and 3 females).
\end{abstract}

cord, telencephalon and hypothalamus, whereas $c G R P$ is weakly expressed in other brain regions (Fig. 7). Within the GI tract, a comparatively high mRNA level of $c G R P$ was detected in the proventriculus, whereas only a very low mRNA level was detected in other parts of the GI tract (Fig. 7). cGRP mRNA is also weakly expressed in the ovary, testes and spleen, while $c G R P$ mRNA is undetectable in other remaining tissues.

Unlike $c G R P R, c B R S 3$ mRNA expression is restricted to several tissues including the testes, subcutaneous fat, skin and brain. Within the CNS, $c B R S 3$ is highly expressed in the telencephalon and weakly in other brain regions including the hypothalamus, while it is undetectable in the spinal cord (Fig. 7).

\section{Characterization of GRP expression in chicken anterior pituitary}

cGRP is expressed in cephalic and caudal lobe of anterior pituitary The extremely abundant mRNA http://jme.endocrinology-journals.org DOI: 10.1530/JME-17-0020
() 2017 Society for Endocrinology Printed in Great Britain 
expression of cGRP in chicken pituitaries led us to further examine whether cGRP protein is highly expressed in the pituitary by Western blot. As shown in Fig. 8, a strong protein band corresponding to cGRP precursor $(\sim 13 \mathrm{kDa})$ was detected in the anterior pituitary. In contrast, only a faint band was detected in the proventriculus, and no visible band detected in the whole brain.

To probe the spatial distribution of cGRP within the anterior pituitary, qPCR, Western blot and immunohistochemical staining (IHC) were conducted. qPCR and Western blot revealed that cGRP mRNA and protein are abundantly expressed in caudal and cephalic lobes of chicken pituitaries. As a control, a protein band of $23 \mathrm{kDa}$ corresponding to cGH was only detected in the caudal lobe (Fig. 8). In accordance with this finding, IHC staining revealed that
cGRP-immunoreactive (cGRP-ir) cells were densely distributed in both lobes (Fig. 8).

CGRP is expressed mainly in LH-cells It is documented that the chicken anterior pituitary contains multiple hormone-producing cells, including somatotrophs (GH-cells) (Harvey et al. 1979), lactotrophs (PRL-cells) (Ohkubo et al. 2000, Liang et al. 2006), corticotrophs (ACTH-cells) and gonadotrophs (e.g. LH-cells) (Proudman et al. 1999, Scanes 2015). To determine whether cGRP is produced by these hormoneproducing cells, double immunofluorescence staining was performed in cultured dispersed pituitary cells. As shown in Fig. 9, approximately $11.7 \%$ of cultured pituitary cells are GRP-ir cells, and the majority of cGRP-ir cells ( 70.6\%) are LH-cells. Moreover, we also noted that most of the

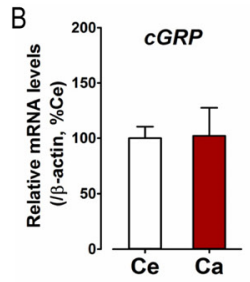

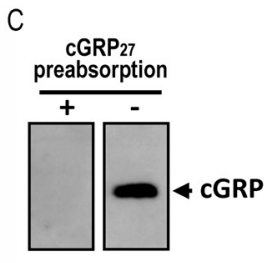
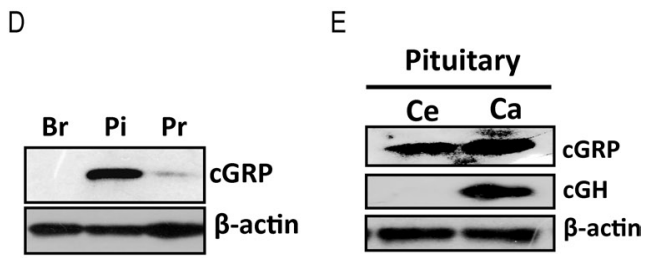
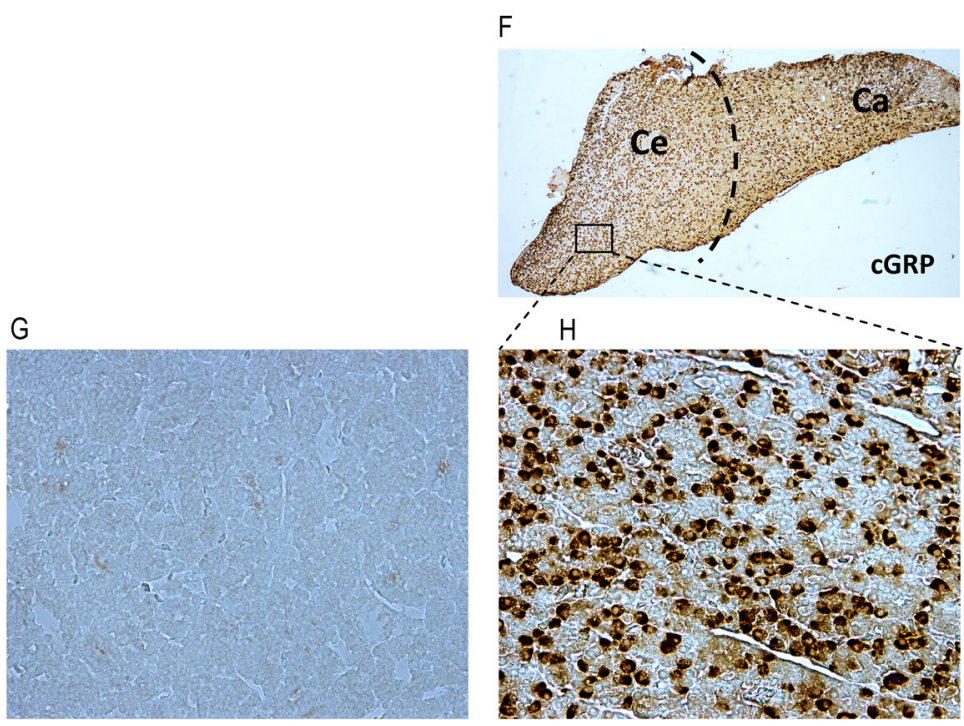

Figure 8

(A) Amplification plot of $c G R P$ and $\beta$-actin using the same amount of adult chicken pituitary CDNA template; (B) qPCR assay of $c G R P$ mRNA levels in the cephalic (Ce) and caudal (Ca) lobes of adult chicken anterior pituitaries. Each data point represents means \pm S.E.M. of five female individuals $(N=5)$; $(C)$ the CGRP band $(13 \mathrm{kDa})$ was detected in pituitary lysate incubated with anti-GRP, whereas CGRP band was not detected in the pituitary lysate incubated with anti-GRP pre-absorbed by $100 \mathrm{ng} / \mathrm{mL} \mathrm{CGRP}_{27}$, validating the specificity of antibody in recognizing GRP expressed in chicken pituitary. (D) Western blot detection of CGRP band (13 kDa) in the whole brain (Br), anterior pituitary (Pi) and proventriculus (Pr) tissue lysates; (E) Western blot detection of cGRP $(13 \mathrm{kDa})$ and $\mathrm{CGH}(23 \mathrm{kDa})$ in the cephalic (Ce) and caudal (Ca) lobes of adult chicken anterior pituitaries. $(\mathrm{F}, \mathrm{G}$ and $\mathrm{H})$ Immuno-histochemical staining of GRP protein in the anterior pituitary of adult female chickens. Histological examination was performed under bright-field illumination with a magnification at $40 \times(\mathrm{F})$ and $400 \times(\mathrm{H})$. GRP-ir cells were densely distributed in both cephalic (Ce) and cephalic (Ca) lobes of anterior pituitaries ( $\mathrm{F}, \mathrm{H})$, whereas no staining was observed in pituitary section incubated with anti-GRP pre-absorbed by $\mathrm{CGRP}_{27}(\mathrm{G})$.

http://jme.endocrinology-journals.org DOI: $10.1530 / \mathrm{JME}-17-0020$ (c) 2017 Society for Endocrinology Printed in Great Britain
Published by Bioscientifica Ltd 
A
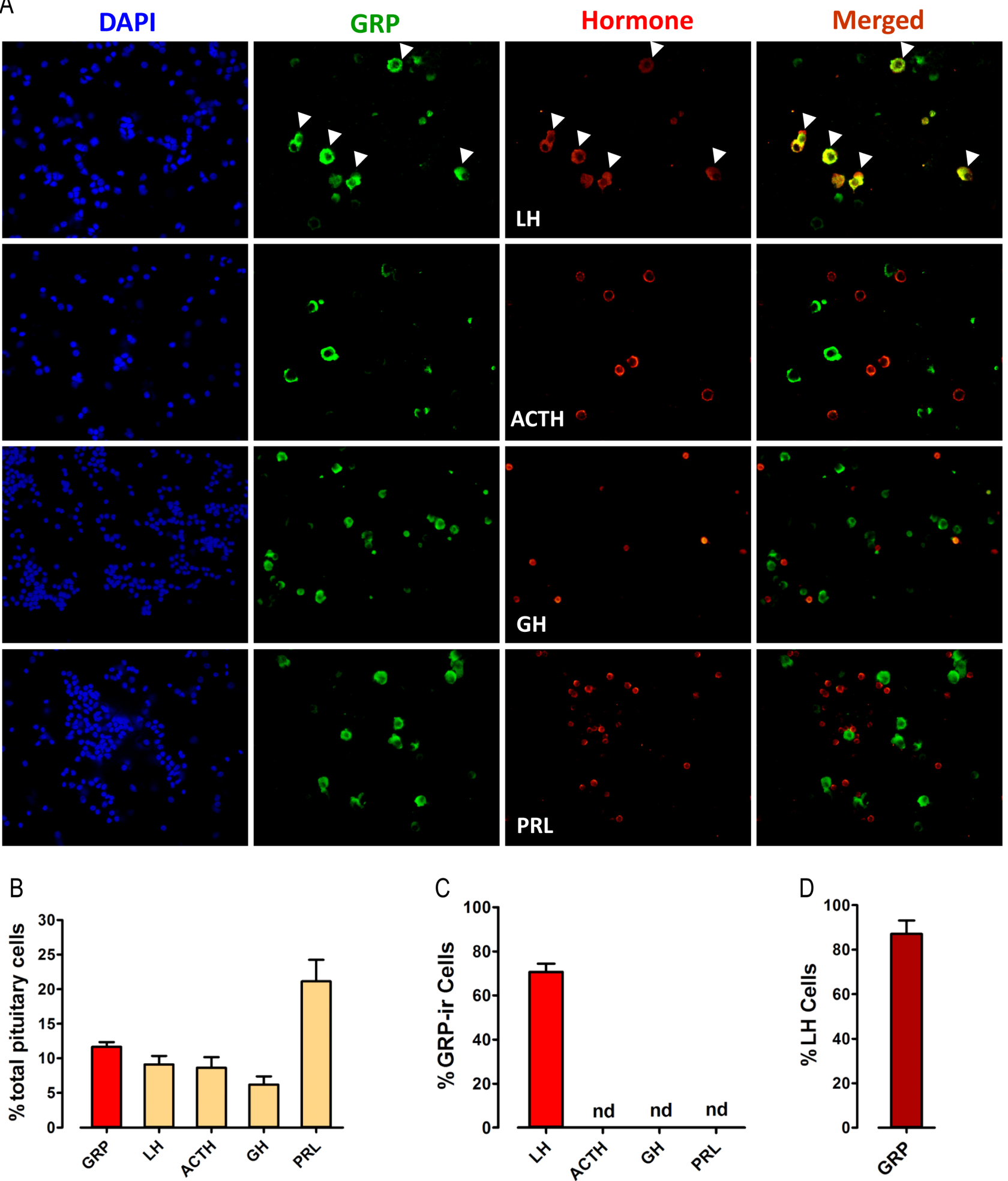

Figure 9

(A) Double immunofluorescence staining showing that cGRP signal (green fluorescence) is mainly localized in LH-cells (top panel, marked by white arrowheads), but not in ACTH-, GH- or PRL-cells in cultured pituitary cells of adult female chickens. (B) Graph shows the relative proportion (\%) of GRP-ir cells $(\sim 11.7 \%)$, LH-cells $(\sim 9.1 \%)$, ACTH-cells $(\sim 8.6 \%)$, GH-cells $(\sim 6.2 \%)$ and PRL-cells $(\sim 21.2 \%)$ in disperse pituitary cells from adult female chickens. (C) Graph shows that the majority $(\sim 70.6 \%)$ of GRP-ir cells are LH-cells, but not other hormone-producing cells (including ACTH-, GH- and PRL-cells). 'nd' indicates no co-localization with GRP-cells. (D) Graph shows that most of LH-cells ( 87.1\%) are GRP-positive. Each data point in graphs (B), (C) and (D) represents mean \pm s.E.M. of 5 replicates $(N=5)$

\begin{tabular}{|lr} 
http://jme.endocrinology-journals.org & @ 2017 Society for Endocrinology \\
DOI: $10.1530 / \mathrm{JME}-17-0020$ & Printed in Great Britain
\end{tabular}


LH-cells $(\sim 87.1 \%)$ are cGRP-positive. In contrast, cGRP signal was not detected in other hormone-producing cells, including GH-cells, PRL-cells and ACTH-cells. These findings clearly indicate that cGRP is mainly expressed in LH-cells.

\section{Discussion}

In this study, we characterized cNMBR, cBRS3, cGRPR, cGRP and cNMB in chickens. Functional assay demonstrated that cNMBR and cGRPR can be preferentially activated by cNMB and cGRP, respectively, while chicken (/spotted gar) BRS3 can be activated by both cGRP and cNMB effectively, indicating that GRP and NMB are the native ligand for BRS3 in chickens (/spotted gars). qPCR assay revealed that $c G R P R$ is widely expressed in chicken tissues, while $c B R S 3, c N M B R$ and $c N M B$ are mainly expressed in the brain and testes. Furthermore, we found that cGRP is predominantly expressed in the anterior pituitary. To our knowledge, our study represents the first to present a new concept that cGRP is likely a novel pituitary hormone in birds. Meanwhile, the discovery of the endogenous ligands of BRS3 in chickens and spotted gars will facilitate our better understanding of the mysterious roles of BRS3 play in vertebrates.

\section{CNMBR and cGRPR are functional receptors specific to CNMB and CGRP respectively}

In this study, an NMBR orthologous to human $N M B R$ was cloned in chickens. cNMBR shows a high degree of amino acid sequence identity (72-74\%) with NMBR of humans and mice. Functional assays proved that $\mathrm{CNMBR}$ can be preferentially activated by cNMB. This finding is consistent with those observations in mammals, in which NMBR can bind to NMB with higher affinity than to GRP and be preferentially activated by NMB (Wada et al. 1991, Benya et al. 1995). Our findings indicate that, as in mammals (Jensen et al. 2008), cNMBR is a cNMB-specific receptor (Fig. 10).

In parallel, we found that both $\mathrm{cGRP}_{27}$ and $\mathrm{cGRP}_{10}$ are 100 -fold more potent than $\mathrm{CNMB}_{10}$ in activating cGRPR expressed in $\mathrm{CHO}$ cells. This finding coincides with a previous study, in which cGRPR expressed in CHO-K1 cells can bind to $\mathrm{CGRP}_{27}$ with a 1000-fold higher affinity than to porcine $\mathrm{NMB}_{10}$ and its activation causes the elevation of intracellular calcium concentration upon 10-nM GRP 27 treatment (Iwabuchi et al. 2003). The findings from our present and previous studies indicate that, as in mammals (Benya et al. 1995, Jensen et al. 2008), cGRPR is a functional receptor specific to cGRP.
A

In chickens

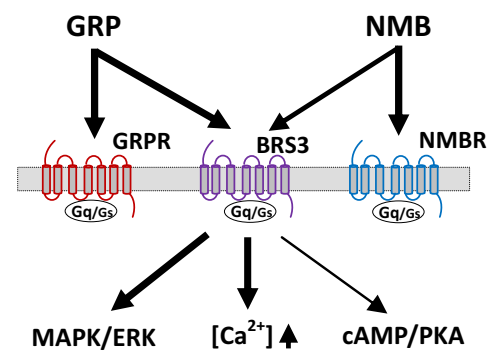

In mammals

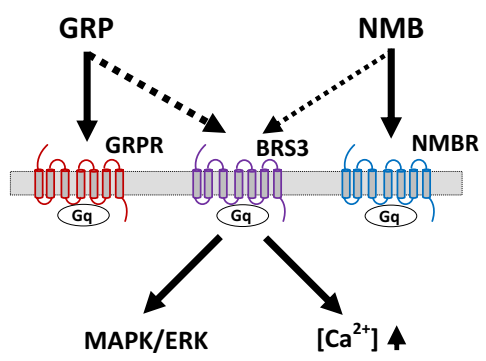

B

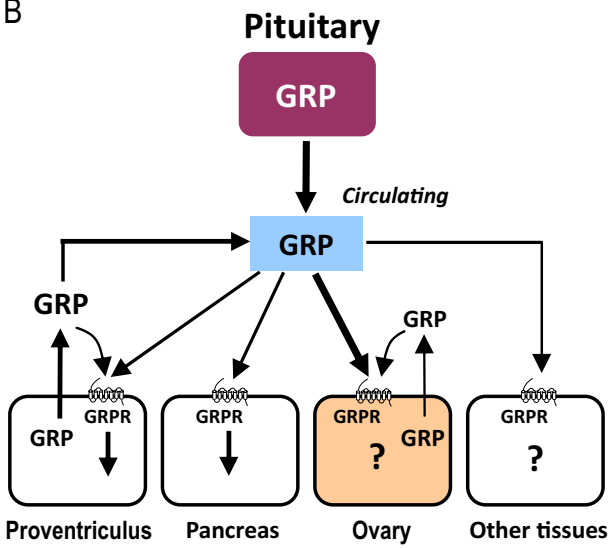

\section{Figure 10}

(A) The bombesin receptors (NMBR, GRPR and BRS3) and their endogenous ligands identified in chickens and mammals. In chickens, GRPR and NMBR function as the receptors specific to GRP and NMB, respectively, whereas BRS3 can be potently activated by GRP and NMB and thus act as a receptor common for both peptides. In mammals, GRPR and NMBR function as the receptors specific to GRP and NMB, respectively, while BRS3 cannot be potently activated by GRP/NMB in vitro ( $E_{50}>>1000 \mathrm{nM}$ ) (Jensen et al. 2008). Interestingly, chicken GRPR, NMBR and BRS3 are likely coupled to Gq and Gs proteins, and their activation triggers calcium mobilization, MAPK/ERK and CAMP/PKA signaling pathways. In contrast, mammalian GRPR, NMBR and BRS3 are coupled to Gq protein, and their activation elevates calcium concentration and stimulates MAPK/ERK signaling pathway (Jensen et al. 2008). (B) The proposed actions of pituitary GRP (a novel pituitary hormone) on chicken peripheral tissues. Pituitary GRP, together with GRP from other tissues (e.g. proventriculus), may contribute to the circulating GRP pool (highlighted in blue) and thus play important roles in the proventriculus, pancreas, ovary and other peripheral tissues in an endocrine (/paracrine/autocrine) manner. The localization of cGRP in pituitary LH-cells (Fig. 9), together with abundant CGRPR expression in the ovary, strongly suggests that GRP-GRPR (marked by bold arrows) may play a critical role in the pituitary-ovary axis of chickens.

http://jme.endocrinology-journals.org DOI: 10.1530/JME-17-0020
๑ 2017 Society for Endocrinology Printed in Great Britain
Published by Bioscientifica Ltd 
It is reported that in mammals, both NMBR and GRPR are coupled to Gq protein, and their activation can lead to IP3 accumulation and DAG production, which subsequently triggers multiple downstream signaling pathways, such as calcium mobilization and ERK signaling pathway (Fig. 10) (Benya et al. 1995, Lach et al. 1995, Jensen et al. 2008). As shown in our study, both cGRPR and cNMBR are also likely coupled to Gq protein, since their activation also increases intracellular calcium concentration and activates ERK signaling cascade, monitored by the cell-based reporter assays. Moreover, we noted that their activation of MAPK/ERK pathway is likely controlled by Gq-PLC. Interestingly, apart from calcium mobilization and MAPK/ERK signaling pathways, AC/ cAMP/PKA signaling pathway is also likely triggered by CGRPR/cNMBR activation, suggesting that both receptors may also be coupled to Gs protein (Fig. 10). Since activation of AC/cAMP/PKA pathway requires higher concentrations of $\mathrm{cGRP} / \mathrm{CNMB}$ than the other pathways, it implies that Gs-AC/cAMP/PKA pathway may represent a secondary signaling pathway for cGRPR/cNMBR. Our finding contrasts with the mammalian study, in which GRPR- or NMBR-transfected cells fail to increase cAMP levels upon ligand stimulation (Benya et al. 1995).

\section{GRP and NMB are the endogenous ligands for chicken/ spotted gar BRS3}

There is growing evidence that BRS3 plays critical roles in the regulation of food intake, body temperature, metabolic rates, obesity, body weight and pancreatic insulin secretion in mice (Ohki-Hamazaki et al. 1997b, Guan et al. 2010, Metzger et al. 2010), and thus, BRS3 has been viewed as a promising therapeutic target to treat obesity and diabetes in humans (Guan et al. 2010, Majumdar \& Weber 2012, Gonzalez et al. 2015). However, unlike NMBR/GRPR, human or mouse BRS3 cannot be effectively activated by GRP/NMB $\left(\mathrm{EC}_{50}>>1000 \mathrm{nM}\right)$, or by any other naturally occurring bombesin-related peptides (Mantey et al. 1997, Ryan et al. 1998). Hence, the native ligand(s) of BRS3 has remained an open question, which has hindered our understanding of the physiological/ pathological roles of BRS3 signaling (Majumdar \& Weber 2012, Gonzalez et al. 2015).

In this study, we found that unlike mouse BRS3, chicken BRS3 can be activated effectively by cGRP and $\mathrm{CNMB}$, with high potencies comparable to those of cGRP/cNMB in activating their specific receptor (cGRPR/ cNMBR) (Table 1). This finding clearly indicates that both
cGRP and CNMB are native ligands for chicken BRS3. Furthermore, we proved that chicken BRS3 activation can trigger calcium mobilization, as demonstrated in mammals (Ryan et al. 1998). Like cGRPR/cNMBR, cBRS3 activation also stimulates MAPK/ERK and AC/CAMP/ PKA/CREB signaling pathways. As in chickens, BRS3 can be effectively activated by GRP and NMB in spotted gars. This finding suggests that GRP and NMB can also act as the endogenous ligands for BRS3 in other lower vertebrate species.

The discovery of native ligands of BRS3 in chickens and spotted gars strongly suggests that GRP and NMB are likely to be the putative native ligand(s) for mammalian BRS3 from an evolutionary perspective. The little or no responsiveness of mammalian BRS3 to GRP/NMB treatment observed in our present and previous studies is likely due to the dramatic structural change of BRS3 during evolution, which may result in the loss of its high affinity to GRP/NMB in vitro (Gorbulev et al. 1992, Mantey et al. 1997, Ryan et al. 1998). Despite the extremely low affinity of mammalian BRS3 to GRP/NMB in vitro, we cannot exclude the possibility that other unidentified accessory protein(s) may be required to aid the effective binding of mammalian BRS3 to GRP/NMB in vivo. Recently, Liu et al. reported that GRPR can heterodimerize with $\mu$-opioid receptor (MOR1D) in mouse spinal cord and mediate the opioid (morphine)-induced scratching behavior (Liu et al. 2011). This finding points out another possibility that like GRPR, BRS3 may heterodimerize with other GPCR(s) and mediate actions of the cognate ligands of its combined receptor.

It is reported that a novel bombesin receptor, named BRS3.5, exists in chickens (Iwabuchi et al. 2003). However, our synteny analysis clearly indicates that chicken $B R S 3.5$ is orthologous to mouse BRS3. Moreover, we demonstrated that chicken BRS3 can be activated by cGRP and CNMB potently. Our finding contrasts with a previous study, in which cBRS3.5 (cBRS3) expressed in CHO-K1 cells binds cGRP $\left(K_{\mathrm{i}}=318 \mathrm{nM}\right)$ or porcine $\mathrm{NMB}\left(K_{\mathrm{i}}=678 \mathrm{nM}\right)$ with an extremely low affinity (Iwabuchi et al. 2003). The discrepancy between the two studies is unclear. However, like chicken BRS3, spotted gar BRS3 can be potently activated by GRP and NMB, substantiating our hypothesis that GRP and NMB are the native ligands of BRS3 in nonmammalian vertebrates (Fig. 10).

In Bombina orientalis, the fourth bombesin receptor subtype (BB4) was identified in 1995 (Nagalla et al. 1995). Pharmacological study showed that BB4 can bind to frog [Phe' ${ }^{13}$-bombesin with an affinity $\left(K_{\mathrm{i}}=0.2 \mathrm{nM}\right)$ higher

Published by Bioscientifica Ltd. 
than to human GRP $\left(K_{\mathrm{i}}=2.1 \mathrm{nM}\right)$ and NMB $\left(K_{\mathrm{i}}=30 \mathrm{nM}\right)$. In addition, [Phe $\left.{ }^{13}\right]$-bombesin treatment causes calcium mobilization in Xenopus oocytes transiently expressing BB4 (Nagalla et al. 1995). Interestingly, we noted that Bombina BB4 share a considerable amino acid sequence identical to chicken/Xenopus tropicalis BRS3 (77\%/84\%) (Supplementary Fig. 4). Moreover, Bombina BB4 is expressed exclusively in the forebrain and cortex (Nagalla et al. 1995), a tissue expression pattern nearly identical to chicken BRS3 (Fig. 7). The remarkable similarity in structure and tissue expression shared between Bombina BB4 and chicken BRS3 led us to hypothesize that Bombina $B B 4$ is orthologous to chicken $B R S 3$, or a BRS3-like receptor duplicated from BRS3 very recently, even though Bombina BB4 has evolved an unusual high affinity to frog [Phe $\left.{ }^{13}\right]$ bombesin peptide (Nagalla et al. 1995), which only exists in some amphibian species (Nagalla et al. 1996).

\section{Tissue expression of BRS3 in chickens}

In this study, $C B R S 3$ is widely expressed in various brain regions with the highest expression noted in the telencephalon. Our finding is consistent with previous reports, in which CBRS3.5 is highly expressed in the telencephalon by RT-PCR or in situ hybridization (Iwabuchi et al. 2003, Ohki-Hamazaki et al. 2005). These findings, together with the expression of $c G R P / c N M B$ detected in these regions (Fig. 7), strongly suggest that cBRS3 can mediate the actions of cGRP/cNMB in chicken CNS. Apart from the CNS, cBRS3 and cNMB/cGRP are also expressed in the testes, adipose tissue and skin, suggesting a role of cBRS3 in mediating cGRP/cNMB actions in these tissues.

It is of particular interest to note that the tissue distribution of $c B R S 3$ is similar, but non-identical, to that in mammals (Ohki-Hamazaki et al. 2005). For instance, $B R S 3$ is expressed in the brain and testes of chickens (Fig. 7), humans (Sano et al. 2004) and rodents (Fathi et al. 1993, Ohki-Hamazaki et al. 1997a); however, within the CNS, an obvious difference in BRS3 distribution has been observed between chickens and mammals. BRS3 is mainly expressed in the hypothalamus of humans and rodents (Ohki-Hamazaki et al. 1997a, 2005, Sano et al. 2004), whereas BRS3 is highly expressed in chicken telencephalon, but not the hypothalamus (Fig. 7) (Ohki-Hamazaki et al. 2005). This remarkable difference hints that hypothalamic BRS3 signaling plays a critical role in mammals such as the control of body weight and metabolic rate (OhkiHamazaki et al. 1997b), while in chicken hypothalamus,
BRS3 signaling is less important and may be functionally replaced by its family member(s), such as $c G R P R$, which is highly expressed in the hypothalamus (Fig. 7).

\section{Tissue expression of NMB and NMBR in chickens}

In this study, $c N M B$ and $C N M B R$ were detected to be widely expressed in the CNS including the hypothalamus (Fig. 7). This finding is consistent with those reports in humans (Sano et al. 2004), pigs (Ma et al. 2016) and rats (Wada et al. 1992), suggesting that CNMB may act as a neuropeptide to regulate some physiological processes, such as food intake, as demonstrated in chickens and mammals (Jensen et al. 2008, Tachibana et al. 2010a,b).

Among the peripheral tissues, the highest mRNA levels of $C N M B$ and $C N M B R$ were noted in the testes (Fig. 7). As in chickens, both NMB and NMBR are highly expressed in the testes of humans (Sano et al. 2004), pigs (Ma et al. 2016) and mice (Ohki-Hamazaki et al. 1997a). These findings strongly suggest that NMB may act as an autocrine/paracrine factor to regulate the functions of testes in vertebrates. In addition, we noted that $c N M B$ is expressed in the ovary and other peripheral tissues. However, the low or no expression of $c N M B R$ in these tissues questions an active role of $\mathrm{CNMB}$ in these tissues.

In this study, $c N M B R$ mRNA is undetectable in the anterior pituitary. This finding contrasts with the observation in rodents. In rats, both $N M B$ and $N M B R$ are expressed in the anterior pituitary, and NMB can act as an autocrine/paracrine factor to inhibit thyroid-stimulating hormone (TSH) release (Rettori et al. 1989, Jones et al. 1992). In mice, disruption of $N M B R$ results in dysregulation of the pituitary-thyroidal axis (Oliveira et al. 2006). The absence of $N M B R$ expression in chicken anterior pituitary hints that unlike mammalian NMB (Rettori et al. 1989), cNMB may not regulate pituitary functions, at least not directly.

\section{Tissue expression of cGRP and cGRPR: evidence for cGRP being a novel potential pituitary hormone}

In this study, we found that $c G R P$ mRNA is widely expressed in the spinal cord and various brain regions (Fig. 7). Similarly, $c G R P R$ is highly or moderately expressed in the spinal cord and nearly all brain regions examined including the hypothalamus. Our findings partially coincide with an early study in chickens, in which GRPR mRNA was reported to be widely expressed in all brain regions detected by RT-PCR (Iwabuchi et al. 2003). http://jme.endocrinology-journals.org DOI: 10.1530/JME-17-0020
○) 2017 Society for Endocrinology Printed in Great Britain
Published by Bioscientifica Ltd 
The wide expression of $c G R P$ and $c G R P R$ also suggests a broad spectrum of GRP actions in chicken CNS, such as inhibition of food intake in the hypothalamus (Tachibana et al. 2010a,b), and itch sensation in the spinal cord, as demonstrated in mammals (Sun \& Chen 2007, Sun et al. 2009).

Outside the CNS, cGRPR is highly expressed in the proventriculus, pancreas and ovary, and weakly in other tissues examined. This finding supports the previous observations in birds, in which GRP or bombesin (an agonist of GRPR) has been shown to stimulate proventriculus acid secretion and pancreatic protein secretion in chickens or turkeys (Linari \& Linari 1975, Campbell et al. 1991, 1994). Unlike $c G R P R, c G R P$ expression is restricted to several peripheral tissues including the GI tract. cGRP mRNA is moderately expressed in the proventriculus, but weakly expressed in other parts of GI tract (Fig. 7). Our data coincide with previous reports, in which GRP was reported to be mainly expressed in the endocrine cells of proventriculus (Vaillant et al. 1979, Buffa et al. 1982, Yamanaka et al. 1989, Scanes \& Pierzchala-Koziec 2014). These findings suggest that cGRP may be secreted into the circulation by these endocrine cells under certain stimuli and thus exert its endocrine/paracrine/autocrine actions on chicken tissues (Fig. 10). Besides proventriculus, both $c G R P$ and $c G R P R$ were detected in the ovary and testes, also supporting an autocrine/paracrine action of GRP on chicken gonads.

The most striking observation of our present study is that $c G R P$ mRNA is abundantly and predominantly expressed in chicken anterior pituitaries. In agreement with this finding, a strong cGRP protein band was detected in anterior pituitaries (Fig. 8). Moreover, qPCR assay showed that the mRNA level of $c G R P$ in the pituitary seems to be even higher than that of $\beta$-actin, as estimated by their amplification plots shown in Fig. 8 , in which $\mathrm{Ct}$ value of $c G R P$ is much lower than that of $\beta$-actin when the same amount of cDNA template was used. These findings not only suggest that the anterior pituitary may be a major source of cGRP in chickens, but also raise the new hypothesis that cGRP is likely a novel pituitary hormone. Our finding contrasts with those in mammals and frogs, in which GRP is mainly produced in the brain and/or gut (Wada et al. 1990, Nagalla et al. 1992), and weakly expressed in the anterior pituitary (Houben et al. 1993).

Using qPCR, IHC and Western blot, we proved that both cGRP mRNA and protein are abundantly expressed in both cephalic and caudal lobes. In accordance with this finding, GRP-ir cells were also shown to be densely distributed in both lobes (Fig. 8), a spatial distribution similar to that of gonadotrophs (e.g. LH-cells), which is distributed throughout both lobes (Proudman et al. 1999, Scanes 2015). Double fluorescence staining further elucidated that GRP-ir cells account for $11.7 \%$ of total pituitary cells, and GRP is mainly expressed in LH-cells (Fig. 9). Moreover, our preliminary study demonstrated that gonadotropin-releasing hormone 1 (GnRH1) can stimulate GRP expression and secretion in cultured chick pituitary cells (data not shown). All these findings support the notion that cGRP is a novel pituitary hormone, which may be released and contribute to a large portion of the circulating cGRP pool (Fig. 10). Considering that cGRPR is highly expressed in the ovary, proventriculus and pancreas, it is likely that pituitary GRP, together with GRP from other tissues (e.g. proventriculus), may act in a coordinated fashion to regulate reproduction, GI tract activity (Campbell et al. 1994) and pancreatic functions (Campbell et al. 1991). Meanwhile, the abundant expression of GRP-GRPR in the pituitary-ovary axis also hints that GRP may be a novel 'gonadotrophic factor' in chickens. Our future study on GRP-GRPR actions in chicken ovary, a dynamic organ showing spectacular granulosa cell proliferation, differentiation and apoptosis, and an extremely high incidence $(30-35 \%$ at 3.5 years of age) of ovarian cancer (Wang et al. 2007b, Johnson \& Giles 2013, Johnson \& Lee 2016), will aid to define the novel facet of roles played by bombesin-like peptides in ovarian physiology/pathology, a topic which has long been neglected in vertebrates.

In summary, chicken GRP, NMB, GRPR, NMBR and BRS3 were characterized in this study. Functional assays revealed that cGRPR and cNMBR can function as the receptors specific to cGRP and $\mathrm{CNMB}$, respectively, while cBRS3 is a functional receptor common for both peptides. Like cBRS3, spotted gar BRS3 can also act as a receptor for GRP and NMB. Moreover, we demonstrated that cGRP is predominantly expressed in the anterior pituitary. Collectively, our study not only presents a new concept that GRP is likely a novel pituitary hormone in chickens, but also identifies GRP and NMB as the native ligands of BRS3 in two representative vertebrate species, an issue that has puzzled endocrinologists for more than two decades. The discovery of the native ligands for BRS3 in non-mammalian species also promotes us to re-think the physiological/pathological roles of BRS3 in mammals, including humans. http://jme.endocrinology-journals.org DOI: 10.1530/JME-17-0020
() 2017 Society for Endocrinology Printed in Great Britain
Published by Bioscientifica Ltd 


\section{Supplementary data}

This is linked to the online version of the paper at $h t t p: / / d x . d o i . o r g / 10.1530 /$ JME-17-0020.

\section{Declaration of interest}

The authors declare that there is no conflict of interest that could be perceived as prejudicing the impartiality of the research reported.

\section{Funding}

This work was supported by grants from the National Natural Science Foundation of China $(31272436,31572391,31271325)$ and the National High Technology Research and Development Program of China (2013AA102501).

\section{References}

Anastasi A, Erspamer V \& Bucci M 1971 Isolation and structure of bombesin and alytesin, 2 analogous active peptides from the skin of the European amphibians Bombina and Alytes. Experientia 27 166-167. (doi:10.1007/BF02145873)

Battey JF, Way JM, Corjay MH, Shapira H, Kusano K, Harkins R, Wu JM, Slattery T, Mann E \& Feldman RI 1991 Molecular cloning of the bombesin/gastrin-releasing peptide receptor from Swiss 3T3 cells PNAS 88 395-399. (doi:10.1073/pnas.88.2.395)

Benya RV, Kusui T, Pradhan TK, Battey JF \& Jensen RT 1995 Expression and characterization of cloned human bombesin receptors. Molecular Pharmacology 47 10-20.

Bu G, Lin D, Cui L, Huang L, Lv C, Huang S, Wan Y, Fang C, Li J \& Wang Y 2016 Characterization of neuropeptide B (NPB), neuropeptide W (NPW), and their receptors in chickens: evidence for NPW being a novel inhibitor of pituitary GH and prolactin secretion. Endocrinology 157 3562-3576. (doi:10.1210/en.2016-1141)

Buffa R, Solovieva I, Fiocca R, Giorgino S, Rindi G, Solcia E, Mochizuch T, Yanaihara C \& Yanaihara N 1982 Localization of bombesin and GRP (gastrin releasing peptide) sequences in gut nerves or endocrine cells. Histochemistry 76 457-467. (doi:10.1007/BF00489901)

Cai G, Mo C, Huang L, Li J \& Wang Y 2015 Characterization of the two CART genes (CART1 and CART2) in chickens (Gallus gallus). PLoS ONE 10 e0127107. (doi:10.1371/journal.pone.0127107)

Campbell B, Garner A, Dimaline R \& Dockray GJ 1991 Hormonal control of avian pancreas by gastrin-releasing peptide from the proventriculus. American Journal of Physiology 261 G16-G21.

Campbell BJ, Garner A, Dockray GJ, Hughes J \& Dimaline R 1994 The mechanism of action of gastrin releasing peptide (GRP) in stimulating avian gastric acid secretion. Regulatory Peptides 49 249-255. (doi:10.1016/0167-0115(94)90147-3)

Cui L, Lv C, Zhang J, Mo C, Lin D, Li J \& Wang Y 2017 Characterization of melanin-concentrating hormone $(\mathrm{MCH})$ and its receptor in chickens: tissue expression, functional analysis, and fasting-induced up-regulation of hypothalamic MCH expression. Gene 615 57-67. (doi:10.1016/j.gene.2017.03.009)

Erspamer V, Erpamer GF \& Inselvini M 1970 Some pharmacological actions of alytesin and bombesin. Journal of Pharmacy and Pharmacology 22 875-876. (doi:10.1111/j.2042-7158.1970.tb08465.x)

Erspamer V, Erspamer GF, Inselvini M \& Negri L 1972 Occurrence of bombesin and alytesin in extracts of the skin of three European discoglossid frogs and pharmacological actions of bombesin on extravascular smooth muscle. British Journal of Pharmacology $\mathbf{4 5}$ 333-348. (doi:10.1111/j.1476-5381.1972.tb08087.x)
Fathi Z, Corjay MH, Shapira H, Wada E, Benya R, Jensen R, Viallet J, Sausville EA \& Battey JF 1993 BRS-3: a novel bombesin receptor subtype selectively expressed in testis and lung carcinoma cells. Journal of Biological Chemistry 268 5979-5984.

Gonzalez N, Moreno P \& Jensen RT 2015 Bombesin receptor subtype 3 as a potential target for obesity and diabetes. Expert Opinion on Therapeutic Targets 19 1153-1170. (doi:10.1517/14728222.2015.1056 154)

Gorbulev V, Akhundova A, Buchner H \& Fahrenholz F 1992 Molecular cloning of a new bombesin receptor subtype expressed in uterus during pregnancy. European Journal of Biochemistry 208 405-410. (doi:10.1111/j.1432-1033.1992.tb17201.x)

Guan XM, Chen H, Dobbelaar PH, Dong Y, Fong TM, Gagen K, Gorski J, He S, Howard AD, Jian T, et al. 2010 Regulation of energy homeostasis by bombesin receptor subtype-3: selective receptor agonists for the treatment of obesity. Cell Metabolism 11 101-112. (doi:10.1016/j.cmet.2009.12.008)

Harvey S, Davison TF \& Chadwick A 1979 Ontogeny of growth hormone and prolactin secretion in the domestic fowl (Gallus domesticus). General and Comparative Endocrinology 39 270-273. (doi:10.1016/0016-6480(79)90121-7)

He C, Zhang J, Gao S, Meng F, Bu G, Li J \& Wang Y 2016 Molecular characterization of three NPY receptors (Y2, Y5 and Y7) in chickens: Gene structure, tissue expression, promoter identification, and functional analysis. General and Comparative Endocrinology 236 24-34. (doi:10.1016/j.ygcen.2016.04.019)

Houben H, Vandenbroucke AT, Verheyden AM \& Denef C 1993 Expression of the genes encoding bombesin-related peptides and their receptors in anterior pituitary tissue. Molecular and Cellular Endocrinology 97 159-164. (doi:10.1016/0303-7207(93)90223-7)

Huang G, He C, Meng F, Li J, Zhang J \& Wang Y 2014 Glucagon-like peptide (GCGL) is a novel potential TSH-releasing factor (TRF) in chickens: (I) evidence for its potent and specific action on stimulating TSH mRNA expression and secretion in the pituitary. Endocrinology 155 4568-4580. (doi:10.1210/en.2014-1331)

Iwabuchi M, Ui-Tei K, Yamada K, Matsuda Y, Sakai Y, Tanaka K \& OhkiHamazaki H 2003 Molecular cloning and characterization of avian bombesin-like peptide receptors: new tools for investigating molecular basis for ligand selectivity. British Journal of Pharmacology 139 555-566. (doi:10.1038/sj.bjp.0705282)

Jensen RT, Battey JF, Spindel ER \& Benya RV 2008 International Union of Pharmacology. LXVIII. Mammalian bombesin receptors: nomenclature, distribution, pharmacology, signaling, and functions in normal and disease states. Pharmacological Reviews 60 1-42. (doi:10.1124/pr.107.07108)

Johnson PA \& Giles JR 2013 The hen as a model of ovarian cancer. Nature Reviews Cancer 13 432-436. (doi:10.1038/nrc3535)

Johnson AL \& Lee J 2016 Granulosa cell responsiveness to follicle stimulating hormone during early growth of hen ovarian follicles. Poultry Science 95 108-114. (doi:10.3382/ps/pev318)

Jones PM, Withers DJ, Ghatei MA \& Bloom SR 1992 Evidence for neuromedin-B synthesis in the rat anterior pituitary gland. Endocrinology 130 1829-1836. (doi:10.1210/en.130.4.1829)

Krane IM, Naylor SL, Helin-Davis D, Chin WW \& Spindel ER 1988 Molecular cloning of cDNAs encoding the human bombesin-like peptide neuromedin B. Chromosomal localization and comparison to cDNAs encoding its amphibian homolog ranatensin. Journal of Biological Chemistry 263 13317-13323.

Lach EB, Broad S \& Rozengurt E 1995 Mitogenic signaling by transfected neuromedin B receptors in Rat-1 cells. Cell Growth and Differentiation 6 1427-1435.

Ladenheim EE, Taylor JE, Coy DH \& Moran TH 1994 Blockade of feeding inhibition by neuromedin B using a selective receptor antagonist. European Journal of Pharmacology 271 R7-R9. (doi:10.1016/0014-2999(94)90291-7) http://jme.endocrinology-journals.org

DOI: 10.1530/JME-17-0020
๑) 2017 Society for Endocrinology Printed in Great Britain 
Liang Y, Cui J, Yang G, Leung FC \& Zhang X 2006 Polymorphisms of 5' flanking region of chicken prolactin gene. Domestic Animal Endocrinology 30 1-16. (doi:10.1016/j.domaniend.2005.05.006)

Linari G \& Linari MB 1975 Effect of bombesin on pancreatic secretion and gall bladder motility of the chicken. European Journal of Pharmacology 34 305-310. (doi:10.1016/0014-2999(75)90256-3)

Liu XY, Liu ZC, Sun YG, Ross M, Kim S, Tsai FF, Li QF, Jeffry J, Kim JY, Loh HH, et al. 2011 Unidirectional cross-activation of GRPR by MOR1D uncouples itch and analgesia induced by opioids. Cell 147 447-458. (doi:10.1016/j.cell.2011.08.043)

Ma Z, Su J, Guo T, Jin M, Li X, Lei Z, Hou Y, Li X, Jia C, Zhang Z, et al. 2016 Neuromedin B and its receptor: gene cloning, tissue distribution and expression levels of the reproductive axis in pigs. PLOS ONE 11 e0151871. (doi:10.1371/journal.pone.0151871)

Majumdar ID \& Weber HC 2012 Biology and pharmacology of bombesin receptor subtype-3. Current Opinion in Endocrinology, Diabetes and Obesity 19 3-7. (doi:10.1097/MED.0b013e32834ec77d)

Mantey SA, Weber HC, Sainz E, Akeson M, Ryan RR, Pradhan TK, Searles RP, Spindel ER, Battey JF, Coy DH, et al. 1997 Discovery of a high affinity radioligand for the human orphan receptor, bombesin receptor subtype 3 , which demonstrates that it has a unique pharmacology compared with other mammalian bombesin receptors. Journal of Biological Chemistry 272 26062-26071. (doi:10.1074/ jbc. 272.41 .26062

Matusiak D, Glover S, Nathaniel R, Matkowskyj K, Yang J \& Benya RV 2005 Neuromedin B and its receptor are mitogens in both normal and malignant epithelial cells lining the colon. American Journal of Physiology: Gastrointestinal and Liver Physiology 288 G718-G728. (doi:10.1152/ajpgi.00156.2004)

McArthur AJ, Coogan AN, Ajpru S, Sugden D, Biello SM \& Piggins HD 2000 Gastrin-releasing peptide phase-shifts suprachiasmatic nuclei neuronal rhythms in vitro. Journal of Neuroscience 20 5496-5502.

McDonald TJ, Jornvall H, Nilsson G, Vagne M, Ghatei M, Bloom SR \& Mutt V 1979 Characterization of a gastrin releasing peptide from porcine non-antral gastric tissue. Biochemical and Biophysical Research Communications 90 227-233. (doi:10.1016/0006291X(79)91614-0)

McDonald TJ, Jornvall H, Ghatei M, Bloom SR \& Mutt V 1980 Characterization of an avian gastric (proventricular) peptide having sequence homology with the porcine gastrin-releasing peptide and the amphibian peptides bombesin and alytesin. FEBS Letters 122 45-48. (doi:10.1016/0014-5793(80)80398-X)

Meng F, Huang G, Gao S, Li J, Yan Z \& Wang Y 2014 Identification of the receptors for somatostatin (SST) and cortistatin (CST) in chickens and investigation of the roles of cSST28, cSST14, and cCST14 in inhibiting cGHRH1-27NH2-induced growth hormone secretion in cultured chicken pituitary cells. Molecular and Cellular Endocrinology 384 83-95. (doi:10.1016/j.mce.2014.01.001)

Merali Z, McIntosh J \& Anisman H 1999 Role of bombesin-related peptides in the control of food intake. Neuropeptides 33 376-386. (doi:10.1054/npep.1999.0054)

Metzger JM, Gagen K, Raustad KA, Yang L, White A, Wang SP, Craw S, Liu P, Lanza T, Lin LS, et al. 2010 Body temperature as a mouse pharmacodynamic response to bombesin receptor subtype-3 agonists and other potential obesity treatments. American Journal of Physiology: Endocrinology and Metabolism 299 E816-E824. (doi:10.1152/ajpendo.00404.2010)

Meyer A \& Van de Peer Y 2005 From 2R to 3R: evidence for a fishspecific genome duplication (FSGD). Bioessays 27 937-945. (doi:10.1002/bies.20293)

Minamino N, Kangawa K \& Matsuo H 1983 Neuromedin B: a novel bombesin-like peptide identified in porcine spinal cord. Biochemical and Biophysical Research Communications 114 541-548. (doi:10.1016/0006-291X(83)90814-8)

Minamino N, Kangawa K \& Matsuo H 1984 Neuromedin C: a bombesinlike peptide identified in porcine spinal cord. Biochemical and
Biophysical Research Communications 119 14-20. (doi:10.1016/0006291X(84)91611-5)

Minamino N, Sudoh T, Kangawa K \& Matsuo H 1985 Neuromedin B-32 and B-30: two 'big' neuromedin B identified in porcine brain and spinal cord. Biochemical and Biophysical Research Communications 130 685-691. (doi:10.1016/0006-291X(85)90471-1)

Mo C, Cai G, Huang L, Deng Q, Lin D, Cui L, Wang Y \& Li J 2015 Corticotropin-releasing hormone $(\mathrm{CRH})$ stimulates cocaine- and amphetamine-regulated transcript gene (CART1) expression through CRH type 1 receptor (CRHR1) in chicken anterior pituitary. Molecular and Cellular Endocrinology 417 166-177. (doi:10.1016/j. mce.2015.09.007)

Moody TW \& Merali Z 2004 Bombesin-like peptides and associated receptors within the brain: distribution and behavioral implications. Peptides 25 511-520. (doi:10.1016/j.peptides.2004.02.012)

Nagalla SR, Gibson BW, Tang D, Reeve JR Jr \& Spindel ER 1992 Gastrinreleasing peptide (GRP) is not mammalian bombesin. Identification and molecular cloning of a true amphibian GRP distinct from amphibian bombesin in Bombina orientalis. Journal of Biological Chemistry 267 6916-6922.

Nagalla SR, Barry BJ, Creswick KC, Eden P, Taylor JT \& Spindel ER 1995 Cloning of a receptor for amphibian [Phe13]bombesin distinct from the receptor for gastrin-releasing peptide: identification of a fourth bombesin receptor subtype (BB4). PNAS 92 6205-6209. (doi:10.1073/ pnas.92.13.6205)

Nagalla SR, Barry BJ, Falick AM, Gibson BW, Taylor JE, Dong JZ \& Spindel ER 1996 There are three distinct forms of bombesin. Identification of [Leu13]bombesin, [Phe13]bombesin, and [Ser3,Arg10,Phe13]bombesin in the frog Bombina orientalis. Journal of Biological Chemistry 271 7731-7737. (doi:10.1074/jbc.271.13.7731)

Ohki-Hamazaki H, Wada E, Matsui K \& Wada K 1997a Cloning and expression of the neuromedin $\mathrm{B}$ receptor and the third subtype of bombesin receptor genes in the mouse. Brain Research 762 165-172. (doi:10.1016/S0006-8993(97)00380-6)

Ohki-Hamazaki H, Watase K, Yamamoto K, Ogura H, Yamano M, Yamada K, Maeno H, Imaki J, Kikuyama S, Wada E, et al. 1997b Mice lacking bombesin receptor subtype-3 develop metabolic defects and obesity. Nature 390 165-169. (doi:10.1038/36568)

Ohki-Hamazaki H, Iwabuchi M \& Maekawa F 2005 Development and function of bombesin-like peptides and their receptors. International Journal of Developmental Biology 49 293-300. (doi:10.1387/ ijdb.041954ho)

Ohkubo T, Tanaka M \& Nakashima K 2000 Molecular cloning of the chicken prolactin gene and activation by Pit-1 and cAMP-induced factor in GH3 cells. General and Comparative Endocrinology 119 208-216. (doi:10.1006/gcen.2000.7507)

Oliveira KJ, Ortiga-Carvalho TM, Cabanelas A, Veiga MA, Aoki K, OhkiHamazaki H, Wada K, Wada E \& Pazos-Moura CC 2006 Disruption of neuromedin $\mathrm{B}$ receptor gene results in dysregulation of the pituitary-thyroid axis. Journal of Molecular Endocrinology 36 73-80. (doi:10.1677/jme.1.01892)

Proudman JA, Vandesande F \& Berghman LR 1999 Immunohistochemical evidence that follicle-stimulating hormone and luteinizing hormone reside in separate cells in the chicken pituitary. Biology of Reproduction 60 1324-1328. (doi:10.1095/ biolreprod60.6.1324)

Rettori V, Milenkovic L, Fahim AM, Polak J, Bloom SR \& McCann SM 1989 Role of neuromedin B in the control of the release of thyrotropin in the rat. PNAS 86 4789-4792. (doi:10.1073/ pnas.86.12.4789)

Rozengurt E 1988 Bombesin-induction of cell proliferation in 3T3 cells. Specific receptors and early signaling events. Annals of the New York Academy of Sciences $\mathbf{5 4 7}$ 277-292. (doi:10.1111/j.1749-6632.1988. tb23896.x)

Ryan RR, Weber HC, Mantey SA, Hou W, Hilburger ME, Pradhan TK, Coy DH \& Jensen RT 1998 Pharmacology and intracellular signaling

Published by Bioscientifica Ltd. 
mechanisms of the native human orphan receptor BRS-3 in lung cancer cells. Journal of Pharmacology and Experimental Therapeutics 287 366-380

Sano H, Feighner SD, Hreniuk DL, Iwaasa H, Sailer AW, Pan J, Reitman ML, Kanatani A, Howard AD \& Tan CP 2004 Characterization of the bombesin-like peptide receptor family in primates. Genomics 84 139-146. (doi:10.1016/j.ygeno.2004.01.008)

Scanes CG 2015 Pituitary gland. In Sturkie's Avian Physiology, 6th ed, pp 497-523. Ed CG Scanes. New York, NY, USA: Academic Press.

Scanes CG \& Pierzchala-Koziec K 2014 Biology of the gastro-intestinal tract in poultry. Avian Biology Research 7 193-222. (doi:10.3184/1758 15514X14162292284822)

Schroeter JC, Fenn CM \& Small BC 2015 Elucidating the roles of gut neuropeptides on channel catfish feed intake, glycemia, and hypothalamic NPY and POMC expression. Comparative Biochemistry and Physiology Part A: Molecular and Integrative Physiology 188 168-174. (doi:10.1016/j.cbpa.2015.06.031)

Spindel ER, Chin WW, Price J, Rees LH, Besser GM \& Habener JF 1984 Cloning and characterization of cDNAs encoding human gastrinreleasing peptide. PNAS 81 5699-5703. (doi:10.1073/pnas.81.18.5699)

Spindel ER, Giladi E, Brehm P, Goodman RH \& Segerson TP 1990 Cloning and functional characterization of a complementary DNA encoding the murine fibroblast bombesin/gastrin-releasing peptide receptor. Molecular Endocrinology 4 1956-1963. (doi:10.1210/mend-412-1956)

Sun YG \& Chen ZF 2007 A gastrin-releasing peptide receptor mediates the itch sensation in the spinal cord. Nature 448 700-703. (doi:10.1038/nature06029)

Sun YG, Zhao ZQ, Meng XL, Yin J, Liu XY \& Chen ZF 2009 Cellular basis of itch sensation. Science 325 1531-1534. (doi:10.1126/ science.1174868)

Tachibana T, Matsuda K, Khan SI, Ueda H \& Cline MA 2010a Feeding and drinking response following central administrations of bombesin-like peptides in chicks. Comparative Biochemistry and Physiology Part A: Molecular and Integrative Physiology 156 394-399. (doi:10.1016/j.cbpa.2010.03.008)

Tachibana T, Matsuda K, Sawa H, Mikami A, Ueda H \& Cline MA 2010 b Differential thresholds of neuromedins B-, C-, and bombesininduced anorexia and crop-emptying rate in chicks. General and Comparative Endocrinology 169 144-150. (doi:10.1016/j. ygcen.2010.08.006)

Vaillant C, Dockray GJ \& Walsh JH 1979 The avian proventriculus is an abundant source of endocrine cells with bombesin-like immunoreactivity. Histochemistry 64 307-314. (doi:10.1007/ BF00495031)
Volkoff H, Peyon P, Lin X \& Peter RE 2000 Molecular cloning and expression of cDNA encoding a brain bombesin/gastrin-releasing peptide-like peptide in goldfish. Peptides 21 639-648. (doi:10.1016/ S0196-9781(00)00199-6)

Wada E, Way J, Lebacq-Verheyden AM \& Battey JF 1990 Neuromedin B and gastrin-releasing peptide mRNAs are differentially distributed in the rat nervous system. Journal of Neuroscience 10 2917-2930.

Wada E, Way J, Shapira H, Kusano K, Lebacq-Verheyden AM, Coy D, Jensen R \& Battery J 1991 cDNA cloning, characterization, and brain region-specific expression of a neuromedin-B-preferring bombesin receptor. Neuron 6 421-430. (doi:10.1016/08966273(91)90250-4)

Wada E, Wray S, Key S \& Battey J 1992 Comparison of gene expression for two distinct bombesin receptor subtypes in postnatal rat central nervous system. Molecular and Cellular Neuroscience 3 446-460. (doi:10.1016/1044-7431(92)90056-8)

Wang Y, Li J, Wang CY, Kwok AH \& Leung FC 2007a Identification of the endogenous ligands for chicken growth hormone-releasing hormone $(\mathrm{GHRH})$ receptor: evidence for a separate gene encoding GHRH in submammalian vertebrates. Endocrinology 148 2405-2416. (doi:10.1210/en.2006-1013)

Wang Y, Li J, Ying Wang C, Yan Kwok AH \& Leung FC 2007b Epidermal growth factor (EGF) receptor ligands in the chicken ovary: I. Evidence for heparin-binding EGF-like growth factor (HB-EGF) as a potential oocyte-derived signal to control granulosa cell proliferation and HB-EGF and kit ligand expression. Endocrinology 148 3426-3440. (doi:10.1210/en.2006-1383)

Wang Y, Wang CY, Wu Y, Huang G, Li J \& Leung FC 2012 Identification of the receptors for prolactin-releasing peptide (PrRP) and Carassius RFamide peptide (C-RFa) in chickens. Endocrinology 153 1861-1874. (doi:10.1210/en.2011-1719)

Xu M \& Volkoff H 2009 Molecular characterization of ghrelin and gastrin-releasing peptide in Atlantic cod (Gadus morhua): cloning, localization, developmental profile and role in food intake regulation. General and Comparative Endocrinology 160 250-258. (doi:10.1016/j.ygcen.2008.12.004)

Yamanaka Y, Yamada J, Kitamura N \& Yamashita T 1989 An immunohistochemical study on the distribution of endocrine cells in the chicken gastrointestinal tract. Zeitschrift fur MikroskopischAnatomische Forschung 103 437-446.

Yun S, Furlong M, Sim M, Cho M, Park S, Cho EB, Reyes-Alcaraz A, Hwang JI, Kim J \& Seong JY 2015 Prevertebrate local gene duplication facilitated expansion of the neuropeptide GPCR superfamily. Molecular Biology and Evolution 32 2803-2817. (doi:10.1093/molbev/msv179)

Received in final form 15 April 2017 Accepted 3 May 2017 http://jme.endocrinology-journals.org

DOI: $10.1530 / J M E-17-0020$
C 2017 Society for Endocrinology Printed in Great Britain
Published by Bioscientifica Ltd 